\title{
Induction of the Hajdu-Cheney Syndrome Mutation in CD19 B Cells in Mice Alters B-Cell Allocation but Not Skeletal Homeostasis
}

Jungeun Yu, ${ }^{* \dagger}$ Stefano Zanotti, ${ }^{* \dagger \dagger}$ Lauren Schilling, ${ }^{\dagger}$ Chris Schoenherr, ${ }^{\S}$ Aris N. Economides, ${ }^{\S}$ Archana Sanjay, ${ }^{* \dagger}$ and Ernesto Canalis* ${ }^{*}$

From the Departments of Orthopaedic Surgery* and Medicine ${ }^{\ddagger}$ and the UConn Musculoskeletal Institute, ${ }^{\dagger}$ UConn Health, Farmington, Connecticut; and Genome Engineering Technologies, ${ }^{\S}$ Regeneron Pharmaceuticals, Tarrytown, New York

Accepted for publication February 27, 2018.

Address correspondence to Ernesto Canalis, M.D., or Archana Sanjay, Ph.D., Department of Orthopaedic Surgery, UConn Health, 263 Farmington Ave., Farmington, CT 06030-5456. E-mail: asanjay@uchc.edu or canalis@ uchc.edu.

\begin{abstract}
Mice harboring Notch2 mutations replicating Hajdu-Cheney syndrome (Notch2 $2^{\text {tm1.1ECan }}$ ) have osteopenia and exhibit an increase in splenic marginal zone B cells with a decrease in follicular B cells. Whether the altered B-cell allocation is responsible for the osteopenia of Notch2 $2^{\text {tm1.1ECan }}$ mutants is unknown. To determine the effect of NOTCH2 activation in B cells on splenic B-cell allocation and skeletal phenotype, a conditional-by-inversion (COIN) Hajdu-Cheney syndrome allele of Notch2 (Notch2 ${ }^{[\triangle P E S T] C O I N}$ ) was used. Cre recombination generates a permanent Notch ${ }^{\triangle P E S T}$ allele expressing a transcript for which sequences coding for the proline, glutamic acid, serine, and threonine-rich (PEST) domain are replaced by a stop codon. CD19-Cre drivers were backcrossed into Notch2 ${ }^{[\triangle P E S T] C O I N /[\triangle P E S T] C O I N}$ to generate CD19-specific Notch2 $2^{\triangle P E S T / \triangle P E S T}$ mutants and control Notch2 ${ }^{[\triangle P E S T] C O I N /[\triangle P E S T] C O I N}$ littermates. There was an increase in marginal zone $B$ cells and a decrease in follicular B cells in the spleen of CD19 ${ }^{\text {Cre/WT }} ;$ Notch $2^{\triangle P E S T / \triangle P E S T}$ mice, recapitulating the splenic phenotype of Notch2 $2^{\text {tm1.1ECan }}$ mice. The effect was reproduced when the NOTCH1 intracellular domain was induced in CD19-expressing cells (CD19 ${ }^{\text {Cre/WT }}$; Rosa ${ }^{\text {Notch1/WT }}$ mice). However, neither CD19 ${ }^{\text {Cre } / W T} ;$;Notch2 ${ }^{\triangle P E S T / \triangle P E S T}$ nor CD19 ${ }^{\text {Cre } / W T} ;$ Rosa ${ }^{\text {Notch1/WT }}$ mice had a skeletal phenotype. Moreover, splenectomies in Notch2 $2^{\operatorname{tm} 1.1 E C a n}$ mice did not reverse their osteopenic phenotype. In conclusion, Notch2 activation in CD19-expressing cells determines B-cell allocation in the spleen but has no skeletal consequences. (Am J Pathol 2018, 188: 1430-1446; https://doi.org/10.1016/ j.ajpath.2018.02.010)
\end{abstract}

Notch are transmembrane receptors that determine cell fate and function. Notch receptors are activated after their interactions with ligands of the Jagged and Delta-like families residing in neighboring cells. ${ }^{1}$ The interactions lead to the proteolytic cleavage of the Notch receptor and the release of its intracellular domain. ${ }^{2}$ The Notch intracellular domain (NICD) translocates to the nucleus, where it forms a ternary complex with recombination signal binding protein for Ig of $\kappa$ region $(\mathrm{RBPJ} \kappa)$ and Mastermind-like. ${ }^{3-5}$ As a consequence, inhibitors of transcription are displaced and coactivators are recruited, and Notch target genes of the hairy enhancer of split (Hes) and Hes-related with YRPW motif families are transcribed. ${ }^{6}$ Although the four Notch receptors share structural properties, their function is not redundant. This has been attributed to distinct patterns of cellular expression, structural differences, and specific interactions of each NICD with RBPJк.

Notch1 is expressed preferentially by $\mathrm{T}$ cells, and its inactivation prevents T-cell development and causes ectopic B-cell formation; Notch1 gain of function has been associated with T-cell acute lymphoblastic leukemia. ${ }^{8,9}$ Notch2 is expressed preferentially by B cells, and its gain of function

Supported by National Institute of Diabetes and Digestive and Kidney Disease grant DK045227 (E.C.) and National Institute of Arthritis and Musculoskeletal and Skin Diseases grants AR063049 (E.C.) and AR068160 (E.C.).

J.Y. and S.Z. contributed equally to this work; A.S. and E.C. contributed equally as senior/corresponding authors to this work.

Disclosures: C.S. and A.N.E. receive stock options from Regeneron Pharmaceuticals. 
has been associated with B-cell lymphomas and lymphomas of the marginal zone of the spleen. ${ }^{10,11}$ Notch2 signaling is required for marginal zone (MZ) B-cell development. ${ }^{12,13}$ NOTCH2 loss-of-function mutations in humans, Notch2 haploinsufficiency, or the conditional inactivation of either Notch2 or Rbpjк in CD19-expressing cells all result in a reduction in the B-cell population of the MZ of the spleen. ${ }^{14-16}$ Accordingly, expression of the NOTCH2 NICD in CD19-expressing cells leads to the reallocation of $\mathrm{B}$ cells to the MZ of the spleen. ${ }^{17}$

Hajdu-Cheney syndrome (HCS) is a rare genetic disease characterized by craniofacial developmental abnormalities, acroosteolysis, and osteoporosis; occasionally, it can present with splenomegaly. ${ }^{18-20}$ HCS is associated with point mutations or short deletions in exon 34 of NOTCH2, leading to the generation of stop codons upstream of the proline $(\mathrm{P})$, glutamic acid (E), serine (S), and threonine (T)-rich (PEST) domain, which is necessary for the degradation of NOTCH2. ${ }^{21-25}$ As a consequence, the mutations result in the translation of a stable protein product and gain-ofNotch2 function. ${ }^{22-27}$

To gain an understanding of the pathophysiology of HCS, a mouse model harboring a Notch 2 mutation $(6955 \mathrm{C}>\mathrm{T})$ in exon 34, upstream of the PEST domain (hence reproducing the HCS mutation), was engineered and termed Notch2 $2^{\text {tml.1ECan }} .^{26}$ The Notch $2^{\text {tml.1ECan }}$ mutant mouse exhibits osteopenia as well as a B-cell phenotype, with reallocation of B cells to the MZ of the spleen. ${ }^{28}$ Although B cells are presumed to affect skeletal homeostasis, it is not known whether the osteopenia of the Notch2 $2^{\text {tml.1ECan }}$ mutant is related to the observed alteration in B-cell lineage allocation. ${ }^{29-31}$

Splenic as well as bone marrow B cells are considered a source of receptor activator of nuclear factor $\kappa \mathrm{B}$ ligand (RANKL), and the production of RANKL by B cells contributes to the bone loss induced by estrogen deficiency and the bone erosion of rheumatoid arthritis. ${ }^{32-34}$ These observations suggest a role for B-cell-derived RANKL in osteoclastogenesis, but it is not known whether the effect of Notch2 on B-cell allocation in the spleen influences the skeleton and whether the reallocation of B cells is a Notch2specific function. To address these questions, Notch2 was activated in CD19-expressing B cells by crossing CD19 Cre mice with a conditional-by-inversion (COIN) mouse model of HCS (Notch2 $\left.2^{[\triangle P E S T] C O I N}\right){ }^{35}$ The model was designed to introduce a stop codon in exon 34 of Notch 2 after Cremediated recombination (Notch $2^{\triangle P E S T}$ ), resulting in the translation of a truncated NOTCH2 protein and, thus, mimicking the genetic defect associated with HCS. The effects of Notch1 gain of function were also examined by crossing CD19 Cre mice with Gt(ROSA)26Sor ${ }^{\text {tml(Notchl)Dam } / J}$ (defined herein as Rosa ${ }^{\text {Notchl }}$ ) mice, where a loxP flanked STOP cassette is placed between the NOTCH1-NICD coding sequence and $G t\left(\right.$ Rosa 26 regulatory elements. ${ }^{36}$ Mice were examined for B-cell allocation in the spleen and bone marrow by flow cytometry and for skeletal phenotypic changes by microcomputed tomography $(\mu \mathrm{CT})$.

\section{Materials and Methods}

\section{Mouse Models}

\section{Notch2 COIN Mice}

The Notch $2^{[\triangle P E S T] C O I N}$ mouse model was generated by introducing an artificial COIN intron into exon 34 of Notch2 in the antisense strand, as recently described. ${ }^{35,37}$ Before Cre recombination, the COIN module is removed by splicing of the precursor mRNA to generate a Notch2 $2^{[\triangle P E S T] C O I N}$ transcript that is indistinguishable from the Notch2 wild-type (Notch2 ${ }^{W T}$ ) mRNA. In the presence of Cre recombinase, the COIN module is brought into the sense strand, causing the irreversible inversion of the allele. The resulting allele, which was termed Notch $2^{\triangle P E S T}$, encodes for a NOTCH2 mutant protein truncated at lysine 2384 lacking the PEST domain. ${ }^{35}$ After the removal of the neo selection cassette, Notch $2^{[\triangle P E S T] C O I N}$ mice were maintained in a $129 \mathrm{SvJ} / \mathrm{C} 57 \mathrm{BL} / 6 \mathrm{~J}$ background.

Induction of the HCS Mutation in the Germline and in CD19Expressing Cells

To achieve systemic inversion of the Notch2 $2^{[\triangle P E S T] C O I N}$ allele, $\mathrm{F}_{1}$ heterozygous Notch2 $2^{[\triangle P E S T] C O I N / W T}$ male mice were bred with female mice expressing Cre under the control of the Hprt promoter (Jackson Laboratory, Bar Harbor, ME) ${ }^{38}$ This resulted in the germline inversion of the COIN module and consequent generation of mice heterozygous for the Notch $2^{\triangle P E S T}$ allele. ${ }^{35}$ The latter were backcrossed into a C57BL/6J genetic background and crossed with wild-type C57BL/6J mice to generate Notch2 ${ }^{\triangle P E S T / W T}$ experimental and wild-type control littermates for phenotypic characterization.

C57BL/6J mice in which the Cre coding sequence was inserted into the endogenous $C D 19$ locus (CD19 Cre; Jackson Laboratory) were used to express Cre recombinase in the B-cell lineage. ${ }^{39}$ To study the activation of the HCS mutation in CD19-expressing cells, the Notch2 $2^{[\triangle P E S T] C O I N}$ allele was introduced into $C D 19^{C r e / W T}$ mice, and CD $19^{\text {Cre/WT }} ;$ Notch2 $2^{[\triangle P E S T] C O I N /[\triangle P E S T] C O I N}$ mice were crossed with Notch2 $2^{[\triangle P E S T] C O I N /[\triangle P E S T] C O I N}$ mice for the generation of $C D 19^{\mathrm{Cre} / W T}$;Notch2 ${ }^{\triangle P E S T / \triangle P E S T}$ experimental and Notch2 $2^{[\triangle P E S T] C O I N /[\triangle P E S T] C O I N}$ littermate controls.

Induction of the NOTCH1-NICD in CD19-Expressing Cells To induce the NOTCH1-NICD in CD19 cells, Rosa ${ }^{\text {Notch1/WT }}$ mice in a C57BL/6J genetic background (Jackson Laboratory) were used. ${ }^{36,40}$ In this model, the $G t($ Rosa) 26 locus is targeted with a DNA construct encoding the NOTCH1NICD, preceded by a loxP-flanked STOP cassette, cloned downstream of the $G t($ Rosa $) 26$ promoter, so that the NICD is expressed on excision of the STOP cassette by Cre recombination. Homozygous Rosa ${ }^{\text {Notchl/Notchl }}$ mice were crossed with heterozygous $C D 19^{C r e / W T}$ mice to generate $C D 19^{\text {Cre/WT }} ; R_{\text {osa }}{ }^{\text {Notchl/WT }}$ experimental mice and Rosa ${ }^{\text {Notch } 1 / W T}$ littermate controls. 
Table 1 Primers Used for Genotyping and Determination of Cre-Mediated Recombination by PCR

\begin{tabular}{|c|c|c|c|}
\hline Allele & Strand & Sequence & Amplicon size, bp \\
\hline \multicolumn{4}{|l|}{ Genotyping } \\
\hline CD19 ${ }^{\text {Cre }}$ & Forward & $5^{\prime}$-GCGGTCTGGCAGTAAAAACTATC- $3^{\prime}$ & 100 \\
\hline \multirow[t]{2}{*}{$C D 19^{W T}$} & Forward & 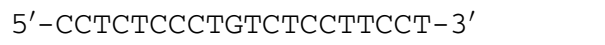 & 500 \\
\hline & Reverse & 5'-TGGTCTGAGACATTGACAATCA-3' & \\
\hline Fabp1 & Forward & 5'-TGGACAGGACTGGACCTCTGCTTTCC-3' & 200 \\
\hline$H p r t^{W T}$ & Reverse & 5'-CACAGTAGCTCTTCAGTCTGATAAAA-3' & \\
\hline \multirow[t]{2}{*}{$H p r t^{C r e}$} & Forward & $5^{\prime}$-GCGGTCTGGCAGTAAAAACTATC- $3^{\prime}$ & 100 \\
\hline & Reverse & $5^{\prime}$-GTGAAACAGCATTGCTGTCACTT-3' & \\
\hline \multirow[t]{2}{*}{ Notch $2^{[\triangle P E S T] C O I N}$} & Forward & $5^{\prime}-$ CCGGGCCGCGACTGAAACCCTAG- $3^{\prime}$ & 330 \\
\hline & Reverse & $5^{\prime}-\mathrm{CCACCACCTCCAGGAGTTGGGC-3^{ \prime }}$ & \\
\hline \multirow[t]{3}{*}{ Rosa $a^{\text {Notch1 }}$} & Forward & 5'-GGAGCGGGAGAAATGGATATG-3' & WT $=600$ \\
\hline & Reverse WT & 5'-AAAGTCGCTCTGAGTTGTTATTG-3' & Rosa ${ }^{\text {Notch1 }}$ NICD $=250$ \\
\hline & Reverse Rosa $a^{\text {Notch } 1}$ NICD & $5^{\prime}$-GCGAAGAGTTTGTCCTCAACC-3' & \\
\hline \multicolumn{4}{|l|}{ LoxP recombination } \\
\hline \multirow[t]{2}{*}{ Notch $2^{[\triangle P E S T] C O I N}$} & Forward & 5'-GTACTTCAGCACAGTTTTAGAGAAC-3' & Not recombined and not detected \\
\hline & Reverse & 5'-GTGAGTCACCCGCCGGATGTC-3' & Recombined $=250$ \\
\hline \multirow[t]{3}{*}{ Rosa $a^{\text {Notch1 }}$} & Forward & 5'-TTCGCGGTCTTTCCAGTGG-3' & Not recombined $=500$ \\
\hline & $\begin{array}{l}\text { Reverse absent loxP } \\
\text { recombination }\end{array}$ & $5^{\prime}$-AGCCTCTGAGCCCAGAAAGC- $3^{\prime}$ & Recombined $=300$ \\
\hline & $\begin{array}{l}\text { Reverse present lox } P \\
\text { recombination }\end{array}$ & $5^{\prime}$-GCCGACTGAGTCCTCGCC- $3^{\prime}$ & \\
\hline
\end{tabular}

NICD, Notch intracellular domain; WT, wild type.

\section{Hajdu-Cheney Global Notch2 $2^{\text {tm1.1ECan }}$ Mutant Mice}

To generate a global mutant mouse model of HCS, a $6955 \mathrm{C}>\mathrm{T}$ substitution was introduced into the mouse Notch2 locus by homologous recombination, as previously reported. ${ }^{26}$ After the removal of the neomycin selection cassette and confirmation of the Notch 2 mutation by sequencing of genomic DNA, mice were backcrossed into a C57BL/6J background for eight or more generations. Heterozygous Notch $2^{\text {tm1.1ECan }}$ mutant and control sex-matched littermate controls were obtained by crossing heterozygous mutant Notch2 $2^{\text {tm1.1ECan }}$ mice with wild-type mice.

\section{Genotyping and Verification of LoxP Recombination}

Allelic composition was determined by PCR analysis of tail DNA with specific primers (all primers from Integrated DNA Technologies, Coralville, CA) (Table 1). Inversion of the COIN module in spleen and bone marrow cells from CD $19^{C r e / W T}$;Notch2 ${ }^{\triangle P E S T / \triangle P E S T}$ mice and deletion of the STOP cassette in spleen cells from CD19 Cre/WT; Rosa ${ }^{\text {Notch } 1 / W T}$ mice were documented by PCR analysis of genomic DNA with specific primers (Table 1).

\section{Splenectomies}

Notch $2^{\text {tm1.1ECan }}$ global mutants and control littermate mice were anesthetized with 3\% isoflurane (Butler Schein Animal Health, Dublin, $\mathrm{OH}$ ), and a dorsal incision was made midway between the rib cage and the hip. The spleen was removed after the ligation of the gastrosplenic ligament and splenic blood vessels by transecting the ligament distal of the ligated vessels, and the abdominal wall was closed. For sham interventions, the spleen was exposed but not resected. Animals were given buprenorphine (Butler Scheim Animal Health), $50 \mu \mathrm{g}$, before and immediately after surgery, and then $100 \mu \mathrm{g}$ twice daily for 48 hours for analgesia. Mice were sacrificed 1 month after the intervention for the characterization of their skeletal phenotype, performed in a blinded manner.

Animals were housed in a pathogen-free facility in groups of one to five per cage and fed commercially available chow (ENVIGO, Madison, WI). Animals appeared healthy during the study, were not immunocompromised, and did not exhibit obvious adverse events. All animal studies were approved by the Institutional Animal Care and Use Committee of UConn Health (Farmington, CT). 
Table 2 Primers Used for RT-qPCR Determinations

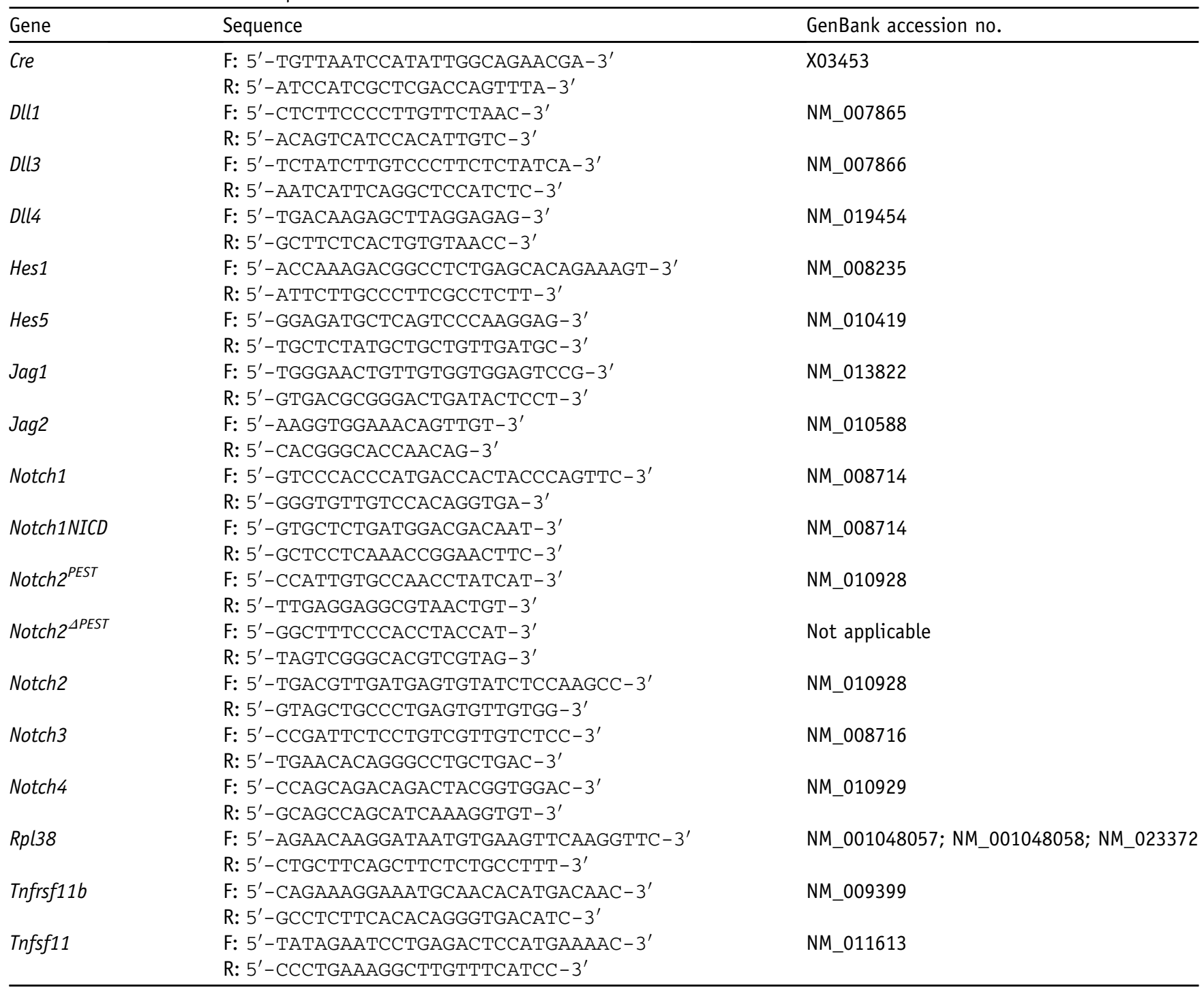

GenBank accession numbers identify the transcripts recognized by primer pairs (https://www.ncbi.nlm.nih.gov/nuccore).

F, forward; R, reverse; RT-qPCR, real-time quantitative RT-PCR.

\section{Immunofluorescence}

To generate frozen sections for immunofluorescence, spleens were fixed in $1 \%$ paraformaldehyde overnight, exposed to $30 \%$ sucrose overnight at $4{ }^{\circ} \mathrm{C}$, and embedded in OCT medium (Thermo Fisher Scientific, Waltham, MA). Sections (7 $\mu \mathrm{m}$ thick) were cut, hydrated in phosphate-buffered saline, and treated with Alexa Fluor 647-conjugated antiCD169 $9^{(\mathrm{MOMA}-1)}$ clone or phycoerythrin-conjugated antiIgM antibodies (BioLegend, San Diego, CA) at a 1:100 dilution. Sections were counterstained with DAPI (Thermo Fisher Scientific) and mounted for fluorescence imaging. Sections were viewed on a Leica fluorescence microscope (model DMI6000B), and collected images were processed using the Leica Application Suite x 1.5.1.1387 (Leica Microsystems, Buffalo Grove, IL).

\section{Flow Cytometry}

To release splenocytes, spleens were disrupted by gentle pressure of the organ between two glass slides. Bone marrow cells were obtained by flushing femurs and tibias with a 26-gauge needle, after the removal of both epiphyseal ends. After the lysis of erythrocytes using a buffer containing $150 \mathrm{mmol} / \mathrm{L}$ ammonium chloride, $10 \mathrm{mmol} / \mathrm{L}$ potassium chloride, $0.1 \mathrm{mmol} / \mathrm{L}$ EDTA (ACK lysis buffer), approximately $4 \times 10^{6}$ cells per mouse were collected in cell-staining medium containing 4-(2-hydroxyethyl)1-piperazineethanesulfonic acid (Sigma Aldrich, St. Louis, MO) and 2\% heat-inactivated fetal bovine serum (Gibco, Hampton, NH) in Hanks' balanced salt solution. Flow cytometry was performed using the following antibodies: anti-CD19, phycoerythrin/Dazzle 594, clone 6D5, 
anti-CD117 Brilliant Violet 421, clone 2B8, anti-IgM phycoerythrin, clone RMM-1, anti-CD45 allophycocyaninCy7, clone 3D-F11, anti-CD23 Brilliant Violet 510, clone B3B4, anti-CD21/CD35 phycoerythrin-Cy7, clone 7G9 (all from BioLegend), and anti-CD45R Alexa Fluor 700, clone RA3-6B2 (eBioscience, Santa Clara, CA). Cells were stained for live-dead cells with Zombie UV dye (BioLegend) at a 1:200 dilution, incubated with antibodies at a concentration of $0.1 \mu \mathrm{g} / 10^{6}$ cells in $100 \mu \mathrm{L}$ staining medium for 1 hour on ice, washed in cell staining medium, and analyzed using a BDLSRII flow cytometer (BD Biosciences, San Jose, CA). After gating for live-dead cell staining and background staining using isotype controls, the relative number of various cell populations was analyzed using FlowJo software version 10.2 (Tree Star, Ashland, OR).

\section{RNA Extraction from Spleen and Bone Marrow Cells and RNA Integrity}

Splenocytes were released after disruption of the spleen, and bone marrow cells were harvested by centrifugation of femurs after removal of the distal epiphysis. In one experiment, cells from wild-type C57BL/6J mice were enriched in CD19-expressing splenocytes $\left(\mathrm{CD} 19^{+}\right)$by magnetic positive selection of spleen suspensions using an autoMacs proseparator system (Miltenyi Biotec, San Diego, CA). Splenocytes depleted of CD19-expressing cells (CD19-) after separation also were collected. Total RNA was extracted from homogenized splenocytes, bone marrow cells, and $\mathrm{CD}_{1} 9^{+}$and $\mathrm{CD} 19^{-}$spleen cells with an RNeasy kit, in accordance with manufacturer's instructions (Qiagen, Valencia, CA). The integrity of the RNA was tested by microfluidic electrophoresis (Experion system; Bio-Rad, Hercules, CA), and only RNA with a quality indicator number of seven or higher was used for analysis of gene expression.

\section{Quantitative RT-PCR}

Equal amounts of RNA were reverse transcribed using iScript RT-PCR kit (Bio-Rad), according to manufacturer's instructions, and amplified in the presence of specific primers (all primers from Integrated DNA Technologies) (Table 2) and iQ SYBR Green Supermix (Bio-Rad), at $60^{\circ} \mathrm{C}$ for 35 cycles. ${ }^{41,42}$ Transcript copy number was estimated by comparing to a serial dilution of cDNA for Dll1 (Emmanuelle Six, Institut Imagine, Paris, France), Dll3, Dll4, and Jag2 (GE Healthcare Dharmacon, Lafayette, CO), Cre, Jag1, and Notch2 (Thermo Fisher Scientific), Hes1 and Tnfrsfl1b, encoding for osteoprotegerin, and ribosomal protein L38 (Rpl38; ATCC, Manassas, VA), Hes5 (from Ryoichiro Kageyama, Kyoto University, Kyoto, Japan), Notch1 and Notch1NICD (Jeffrey S. Nye, Janssen Research and Development Labs, LaJolla, CA), Notch4 (Yasuaki Shirayoshi, Tottori University, Tottori, Japan), and Tnfsf11 (Source BioScience, Nottingham, UK). ${ }^{43-46}$ Notch $2^{\triangle P E S T}$ transcripts were detected with primers that generate an amplicon straddling the artificial splice junction generated within exon 34 of the targeted Notch2 locus on inversion of the COIN module (Table 2). Primers are specific for the Notch $2^{\triangle P E S T}$ mRNA and do not recognize the wild-type Notch2 transcript or the Notch2 ${ }^{[\triangle P E S T] C O I N}$ mRNA before COIN inversion. Notch $2^{\triangle P E S T}$ and Notch 3 copy number was estimated by comparison to a serial dilution of an approximately 200-bp synthetic DNA template (Integrated DNA Technologies) cloned into pcDNA3.1( ${ }^{-}$) (Thermo Fisher Scientific) by isothermal single-reaction assembly using commercially available reagents (New England BioLabs, Ipswich, MA) ${ }^{47}$ To monitor for the efficiency of the COIN inversion, primers designed to amplify a sequence of the Notch2 transcript coding for the PEST domain were used, and the respective PCR product was termed Notch2 $2^{\text {PEST }}$ (Table 2). These primers allow the detection, by real-time quantitative RT-PCR, of the transcripts for Notch $2^{W T}$ and Notch $2^{[\triangle P E S T] C O I N}$, but not for Notch2 ${ }^{\triangle P E S T}$, because the latter lacks the sequences coding for the PEST domain. Notch $2^{\text {PEST }}$ copy number was measured by comparing with a serial dilution of Notch2 cDNA (Thermo Fisher Scientific).

Amplification reactions were conducted in CFX96 realtime quantitative RT-PCR detection systems (Bio-Rad), and fluorescence was monitored during every PCR cycle at the annealing step. Data are expressed as copy number corrected for $R p l 38$ expression, estimated by comparison with a serial dilution of $R p l 38$ (ATCC). ${ }^{48}$

\section{Microcomputed Tomography}

Femoral microarchitecture was determined using a microcomputed tomography instrument (Scanco $\mu \mathrm{CT}$ 40; Scanco Medical AG, Brütisellen, Switzerland), which was calibrated periodically using a phantom provided by the manufacturer. ${ }^{49,50}$ Femurs were scanned in $70 \%$ ethanol at high resolution, energy level of $55 \mathrm{kVp}$, intensity of $145 \mu \mathrm{A}$, and integration time of 200 milliseconds. A total of 100 slices at midshaft and 160 slices at the distal metaphysis were acquired at an isotropic voxel size of $216 \mu^{3}$ and a slice thickness of $6 \mu \mathrm{m}$, and chosen for analysis. Trabecular bone volume fraction (bone volume/total volume) and microarchitecture were evaluated starting approximately $1.0 \mathrm{~mm}$ proximal from the femoral condyles. Contours were manually drawn every 10 slices, a few voxels away from the endocortical boundary, to define the region of interest for analysis, whereas the remaining slice contours were iterated automatically. Total volume, bone volume, bone volume fraction, trabecular thickness, trabecular number, connectivity density, structure-model index, and material density were measured in trabecular regions using a gaussian filter $(\sigma=0.8)$ and user-defined thresholds. ${ }^{49,50}$ For analysis of cortical bone, contours were iterated across 100 slices along the cortical shell of the femoral midshaft, excluding the marrow cavity. Analysis of bone volume/total volume, 

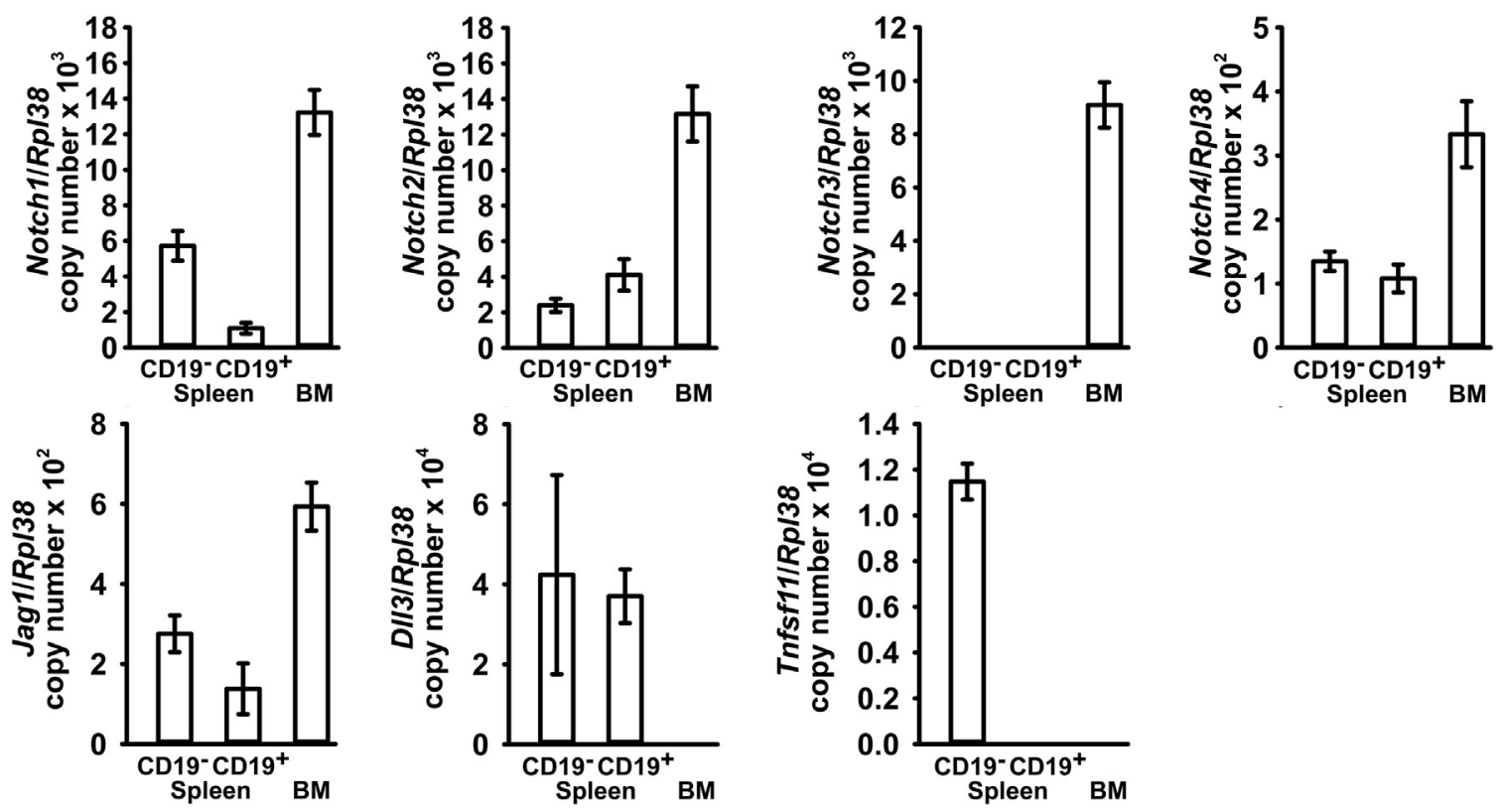

Figure 1 Expression of Notch receptors, cognate ligands, and Tnfsf11 in the spleen and bone marrow (BM). Spleens and femurs were dissected from 7- and 10-week-old wild-type male mice, respectively. Cellular fractions enriched or depleted of CD19-expressing splenocytes (CD19 ${ }^{+}$or CD19-, respectively) were obtained from spleen suspensions, and bone marrow cells were harvested from femurs, by centrifugation. Total RNA was extracted from isolated cells, and mRNA was quantified by real-time quantitative RT-PCR in the presence of specific primers. Data are expressed as Notch1, Notch2, Notch3, Notch4, Jag1, Dll3, and Tnfsf11 copy number, corrected for Rpl38 expression. Jag2, Dll1, Dll4, and Tnfrsf11b were not detected in any cell preparation shown. Data are expressed as means \pm SD. $n=3$ splenocytes; $n=4$ bone marrow biological replicates.

porosity, cortical thickness, total cross-sectional and cortical bone area, periosteal and endosteal perimeter, and material density was conducted using a gaussian filter $(\sigma=0.8$, support $=1$ ) with operator-defined thresholds. Technical personnel were blinded to the identity of the animals during analysis.

\section{Statistical Analysis}

Data are expressed as means \pm SD. Statistical differences were determined by $t$-test for pairwise or two-way analysis of variance, with Holm-Š́dák post-hoc analysis for multiple comparisons. To ensure normal data distribution, a ShapiroWilk test was conducted; and to ensure equal variance of the data, a Brown-Forsythe test was applied.

\section{Results}

Expression Pattern of Notch Receptors and Ligands in the Spleen and Bone Marrow

To determine the potential role of Notch receptors and ligands in cellular events in the spleen and bone marrow environment, the expression pattern of Notch receptors and ligands in these organs was determined by real-time quantitative RT-PCR. Notch1, 2, and 4, but not Notch3, were expressed by $\mathrm{CD} 19^{-}$and $\mathrm{CD} 19^{+}$cells of the spleen (Figure 1). All four Notch receptors were expressed by bone marrow cells. Jagged1 (Jagl) was expressed by $\mathrm{CD}_{19^{-}}$and $\mathrm{CD} 19^{+}$spleen cells as well as by bone marrow cells, and Delta-like 3 (Dll3) was expressed only by spleen cells, whereas Jag2, Dll1, and Dll4 were not detected in either spleen or bone marrow cells. RANKL, encoded by Tnfsf11, was expressed by $\mathrm{CD} 19^{-}$but not by $\mathrm{CD} 19^{+}$spleen cells (Figure 1), and its transcript expression in $\mathrm{CD} 19^{+}$bone marrow cells was detected inconsistently (data not shown). Osteoprotegerin expression was not detected in either spleen or bone marrow cells.

\section{Inversion of the Notch2 ${ }^{[\triangle P E S T] C O I N}$ Allele in the Germline Increases Marginal Zone B Cells}

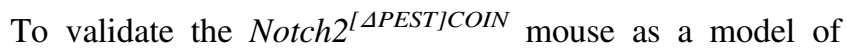
HCS, the spleen phenotype of Notch $2^{\triangle P E S T / W T}$ mice was determined. These mice were generated by crossing Notch2 $2^{[\triangle P E S T] C O I N / W T}$ male mice with heterozygous Hprt ${ }^{\text {Cre }}$ female mice, which brings about the inversion of the COIN module in the germline, causing Notch $2^{\triangle P E S T / W T}$ mice. These mice were crossed with wild-type mice to obtain Notch $2^{\triangle P E S T / W T}$ and control wild-type littermates. Notch2 ${ }^{\triangle P E S T / W T}$ mice appeared healthy, and their weight and spleen weight were not different from controls (Figure 2). COIN inversion was documented by the presence of the Notch $2^{\triangle P E S T}$ allele in DNA from tails of Notch $2^{\triangle P E S T / W T}$ mice. Real-time quantitative RT-PCR analysis of total RNA from spleen documented the expression of the Notch $2^{\triangle P E S T}$ transcript in mutant mice but not in 
A

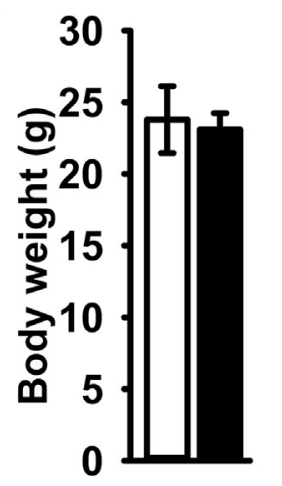

B

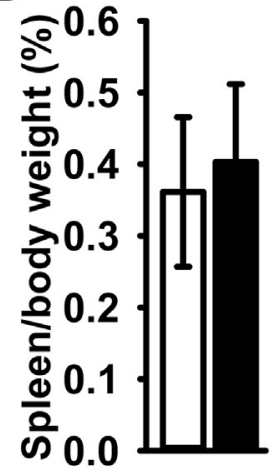

C

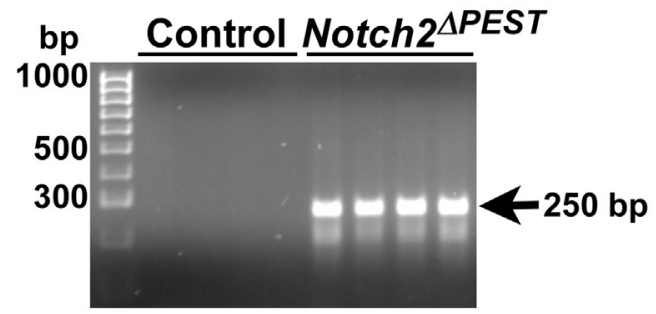

D
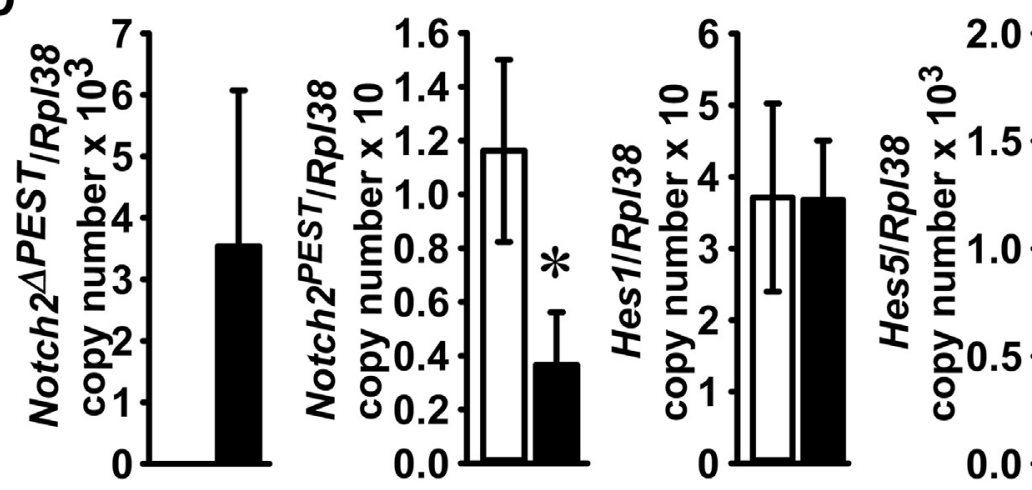

\section{$\square$ Control Notch2 $\triangle P E S T$}

Figure 2 General appearance of Notch2 ${ }^{\triangle P E S T / W T}$ germline mice and Notch signaling in the spleen. Weight, spleen weight, documentation of Notch $2^{[\triangle P E S T] C O I N}$ inversion, and expression of Notch target genes in control and germline Notch2 ${ }^{\text {PPEST/WT }}$ mice. A and B: Body weight (A) and ratio of spleen/ body weight (B) of Notch $2^{4 P E S T / W T}$ and control 2-month-old male mice. C: DNA was extracted from tails, and Notch2 ${ }^{[\triangle P E S T] C O I N}$ inversion was documented by gel electrophoresis of PCR products obtained with primers specific for the Notch $2^{\triangle P E S T}$ allele. The arrow indicates the position of the 250-bp amplicon. D: Total RNA was extracted from spleens, and expression of the Notch $2^{\triangle P E S T}$, Notch2 ${ }^{\text {PEST }}$, Hes1, and Hes5 mRNA was determined by real-time quantitative RT-PCR. Transcript levels are reported as copy number corrected for Rpl38 mRNA levels. Two technical replicates were used for each real-time quantitative RT-PCR. Data for Hes1 mRNA were obtained from 2- and 2.5-month-old mice. Data are expressed as means \pm SD (A, B, and D). $n=4$ biological replicates

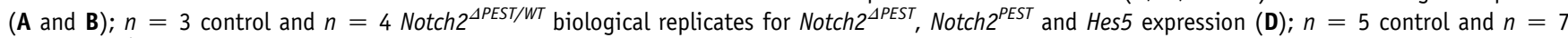
Notch ${ }^{\triangle P E S T / W T}$ biological replicates for Hes1 mRNA levels (D). ${ }^{*} P<0.05$ versus control $(t$-test).

control littermates. The levels of Notch2 transcripts that retain the sequence coding for the PEST domain $\left(\right.$ Notch2 $2^{\text {PEST }}$ ) were approximately $60 \%$ lower in Notch $2^{\triangle P E S T / W T}$ mice than in controls, confirming the inversion event and demonstrating that transcription is interrupted upstream of the PEST domain. The approximately $60 \%$ reduction is congruent with the heterozygosity of the Notch2 $2^{\triangle P E S T}$ allele and indicates that the Notch ${ }^{\triangle P E S T}$ and Notch ${ }^{W T}$ alleles have a comparable level of expression. These effects were associated with increased transcript levels for Hes5, suggesting enhanced Notch signaling (Figure 2).

Flow cytometry of spleen cells from 2-month-old male Notch $2^{\triangle P E S T / W T}$ and littermate control sex-matched mice demonstrated an approximately threefold increase in the percentage of MZ B cells identified as $\mathrm{B}_{2} 20^{+} \operatorname{IgM}^{+} \mathrm{CD} 21 /$ $35^{\text {high }} \mathrm{CD} 23^{-}$cells in Notch $2^{\triangle P E S T / W T}$ mice compared with sex-matched control mice (Figure 3). Accordingly, the mean fluorescence intensity was increased 1.3-fold. In association with this increase in MZ B-cell subset, there was a modest decrease in the percentage of follicular $\left(\mathrm{B} 220^{+} \mathrm{IgM}^{+} \mathrm{CD} 21 /\right.$ $35^{\text {int }} \mathrm{CD} 23^{+}$) B cells in Notch $2^{\triangle P E S T / W T}$ compared with control mice. The results confirm the spleen phenotype of global Notch2 $2^{\text {tm1.1ECan }}$ mutant mice ${ }^{28}$ and validate the Notch $2^{[\triangle P E S T] C O I N}$ model for the study of B-cell phenotypic changes.

\section{Inversion of the Notch $2^{[\triangle P E S T] C O I N}$ Allele in CD19 B Cells Causes an Expansion of Marginal Zone B Cells}

To determine whether the increased B-cell population in the MZ of mice carrying the HCS mutation was driven by a direct effect of Notch2 in B cells, the Notch2 ${ }^{\triangle P E S T}$ mutation was introduced into CD19-expressing cells. For this purpose, CD19 ${ }^{C r e / W T} ;$ Notch2 $^{[\triangle P E S T] C O I N /[\triangle P E S T] C O I N}$ and Notch2 $2^{[\triangle P E S T] C O I N /[\triangle P E S T] C O I N}$ mice were crossed to generate $C D 19^{\mathrm{Cr} / W T} ;$ Notch $2^{\triangle P E S T / \triangle P E S T}$ mice and littermate Notch2 $2^{[\triangle P E S T] C O I N /[\triangle P E S T] C O I N}$ controls. In an initial experiment, flow cytometry of the spleen and bone marrow of $C D 19^{C r e / W T}$ demonstrated no differences in B-cell populations when compared with wild-type littermate controls (data not shown). Flow cytometry demonstrated no 
A

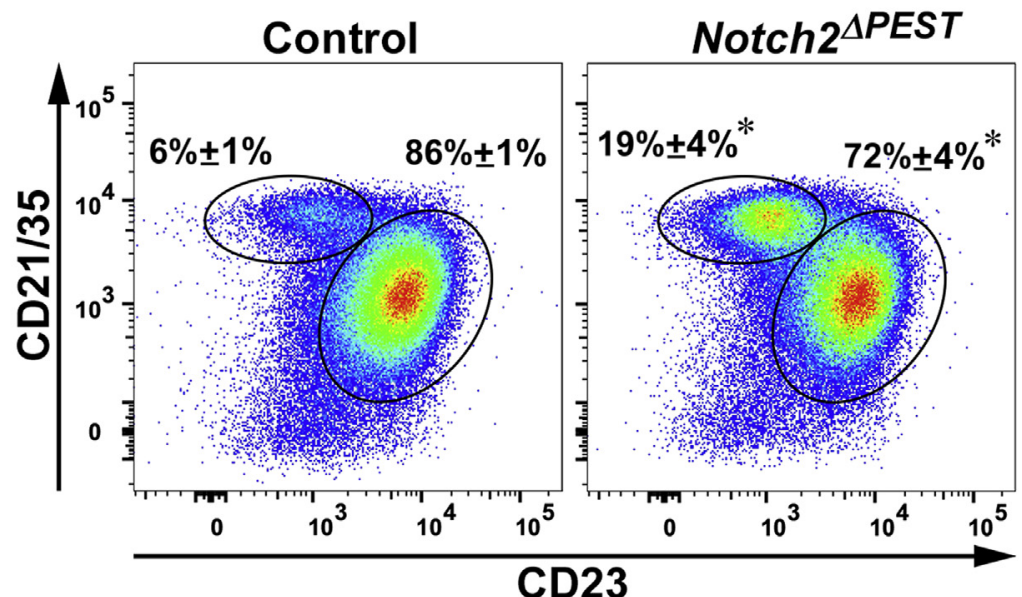

B

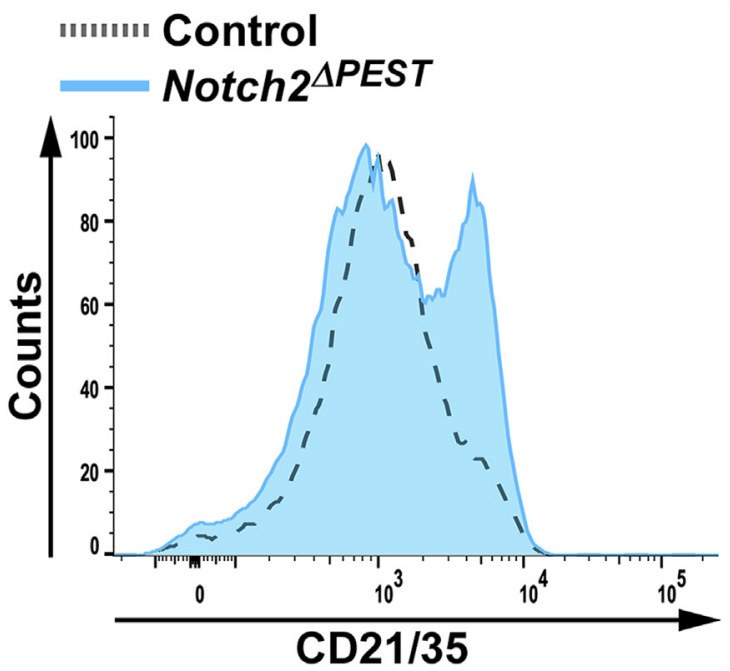

$\square$ Control Notch2 ${ }^{\triangle P E S T}$

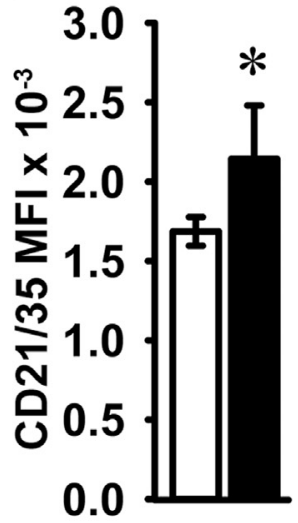

Figure 3 Splenic B-cell allocation in Notch2 ${ }^{\triangle P E S T / W T}$ germline mice. Flow cytometry of spleen cells from control and germline Notch2 $2^{\triangle P E S T / W T}$ mice. A: Representative dot plot of flow cytometry of spleen cells from 2-month-old male Notch $2^{\triangle P E S T / W T}$ and control sex-matched littermates. Cells were stained with anti-CD21/35 and anti-CD23 antibodies. Frequency of CD21/ $35^{\text {high }} \mathrm{CD}^{2} 3^{-}$marginal zone (MZ) B cells and CD21/ $35^{\text {int }} \mathrm{CD} 23^{+}$follicular $\mathrm{B}$ cells gated on $\mathrm{B}_{220^{+}} / \mathrm{IgM}^{+}$ $B$-cell populations is shown. Values represent the percentage of MZ B cells and follicular B cells for four biological replicates. B: Histogram of the mean fluorescence intensity (MFI) of the CD21/35 cell population from 2-month-old germline Notch2 ${ }^{\triangle P E S T / W T}$ and control mice. C: Bar graph of MFI of the CD21/35 cells for control and germline Notch ${ }^{\triangle P E S T / W T}$ mice. Data are expressed as means $\pm \mathrm{SD}(\mathbf{A}$ and $\mathbf{C}) . n=4$ biological replicates for control and experimental mice (A and $\mathbf{C}$ ). ${ }^{\star} P<0.05$ versus control ( $t$-test). differences in bone marrow B-cell populations or follicular $\mathrm{B}$ cells in the spleen between Notch2 $2^{[\triangle P E S T] C O I N /[\triangle P E S T] C O I N}$ and wild-type littermate controls. However, a decrease in MZ B cells from (means $\pm \mathrm{SD} ; n=4) 5.9 \% \pm 1.4 \%$ in controls to $2.1 \% \pm 0.3 \%(P<0.05)$ in Notch $2^{[\triangle P E S T] C O I N /[\triangle P E S T] C O I N}$ was observed.

The general appearance and weight of $C D 19^{C r e / W T}$; Notch $2^{\triangle P E S T / \triangle P E S T}$ mice were not different from controls, although the spleen of female mice was relatively larger than that of controls (Figure 4). Inversion of the COIN allele was detected in DNA from the spleen and bone marrow of CD19 $19^{\text {Cre/WT }}$;Notch2 ${ }^{\triangle P E S T / \triangle P E S T}$ mice but not of littermate controls (Figure 4). Accordingly, the Notch2 ${ }^{\triangle P E S T}$ transcript was detected only in the spleen of $C D 19^{C r e / W T}$; Notch $2^{\triangle P E S T / \triangle P E S T}$ mice, documenting the induction of the HCS mutation in CD19-expressing cells. The presence of the Notch $2^{\triangle P E S T}$ mRNA was associated with an approximately $50 \%$ reduction of Notch $2^{\text {PEST }}$ mRNA and increased transcript levels for Hes 1 and Hes 5 in the spleen, demonstrating increased Notch2 signaling (Figure 4). A lesser degree of Notch $2^{\triangle P E S T}$ expression was observed in bone marrow cells from $C D 19^{\text {Cre/WT }}$;Notch $2^{\triangle P E S T / \triangle P E S T}$ mice, and no appreciable reduction in Notch $2^{P E S T}$ mRNA was noted. This resulted in a lack of induction of the Notch target genes Hes 1 and Hes 5 in the marrow compartment. Although Notch2 is expressed by bone marrow cells (Figure 1), the results indicate a small degree of Notch $2^{\triangle P E S T}$ induction in CD19-expressing bone marrow cells. This was attributed to the greater expression of Cre recombinase in the spleen than in the bone marrow of $C D 19^{C r e}$ mice. $^{39,51}$ In accordance with these observations, $C r$ mRNA levels were (means $\pm \mathrm{SD} ; n=8$ to 11 Cre copy number/Rpl38) $5.7 \pm 2.4$ in the spleen and $1.4 \pm 0.7$ in the bone marrow $(P<0.05)$ of $C D 19^{C r e}$ mice. To ensure Bcell-specific Cre recombination, Cre mRNA transcripts were measured in multiple tissues from $C D 19^{\mathrm{Cre}}$; Notch2 $2^{[\triangle P E S T] C O I N /[\triangle P E S T] C O I N]}$; values (means $\pm \mathrm{SD} ; n=3$; spleen transcripts normalized to 1) for Cre copy number/ $R p l 38$ were $1.0 \pm 0.6$ for spleen, $0.3 \pm 0.1$ for lung, $0.25 \pm 0.1$ for femur, and $0.02 \pm 0.03$ for thymus. Cre mRNA was undetectable in the kidney, liver, and brain. The expression in the femur may represent contamination of the samples by residual bone marrow cells. 
A

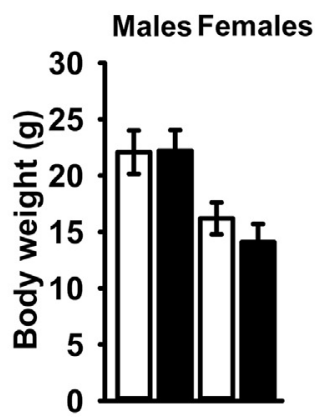

B

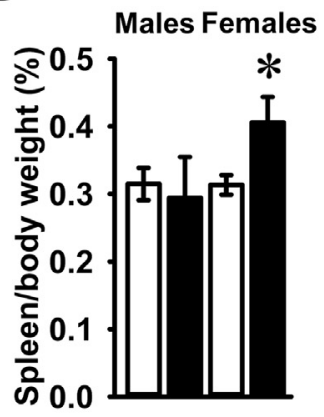

C

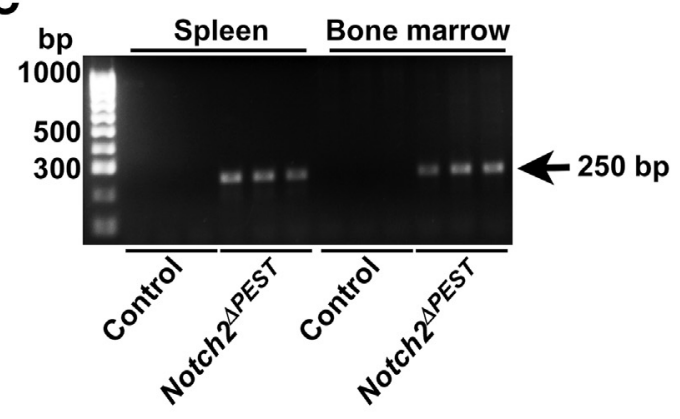

D

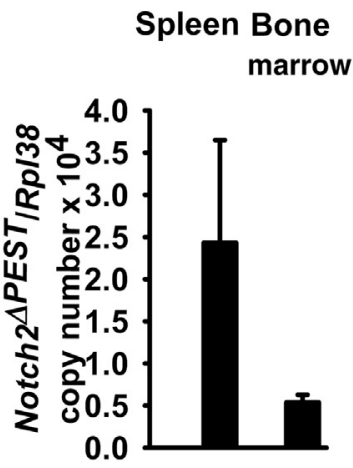

Spleen Bone marrow
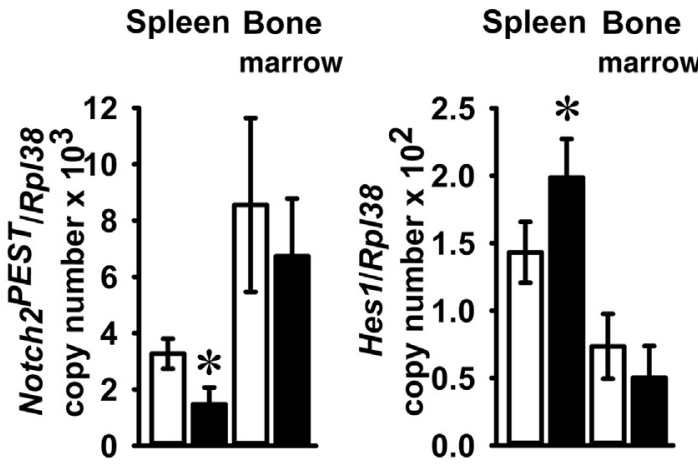

Spleen Bone

marrow

Figure 4 General appearance of $C D 19^{\text {Cre/WT }}$;Notch $2^{\triangle P E S T / \triangle P E S T}$ mice and Notch signaling in the spleen and bone marrow. Weight, spleen weight, documentation of Notch $2^{[\triangle P E S T] C O I N}$ inversion, and expression of Notch2 target genes in control and CD19 $9^{\text {Cre/WT }} ;$ Notch $2^{\triangle P E S T / \triangle P E S T}$ mice. A and B: Body weight (A) and ratio of spleen weight/body weight (B) of 2-month-old control and CD19 ${ }^{\text {Cre/WT }} ;$ Notch2 ${ }^{\triangle P E S T / \triangle P E S T}$ male and female mice. C: DNA was extracted from spleen

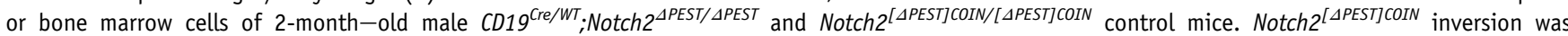
demonstrated by gel electrophoresis of PCR products obtained with primers specific for the Notch $2^{\triangle P E S T}$ allele. The arrow indicates the position of the 250 -bp

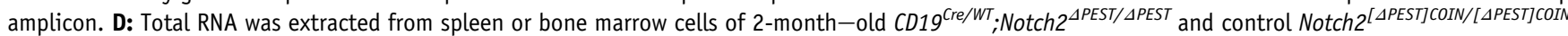
mice, and gene expression was measured by real-time quantitative RT-PCR. Notch $2^{\triangle P E S T}$, Notch2 ${ }^{\text {PEST }}$, Hes1, and Hes5 mRNA copy number corrected for Rpl38

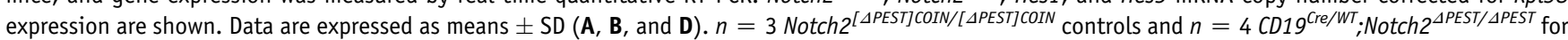

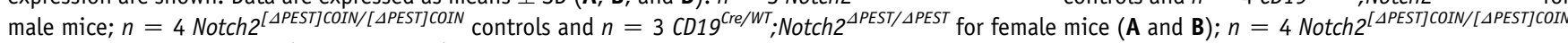
controls and $n=3 \mathrm{CD} 19^{\text {Cre/WT }} ;$ Notch2 ${ }^{\triangle P E S T / \triangle P E S T}$ mice biological replicates (D). ${ }^{*} P<0.05$ versus control ( $t$-test).

Flow cytometry of B cells isolated from the bone marrow demonstrated that the frequency of pre-pro-B $\left(\mathrm{B} 220^{+} \mathrm{CD}_{19}{ }^{-} \mathrm{CD}_{117}^{-} \mathrm{IgM}^{-}\right)$, pro-B $\left(\mathrm{B} 220^{+} \mathrm{CD} 19^{+}\right.$ $\left.\mathrm{CD} 117^{+} \mathrm{IgM}^{-}\right)$, pre-B $\left(\mathrm{B} 220^{+} \mathrm{CD} 19^{+} \mathrm{CD} 117^{-} \mathrm{IgM}^{-}\right)$, and immature $\left(\mathrm{B} 220^{+} \mathrm{CD} 19^{+} \mathrm{CD} 117^{-} \mathrm{IgM}^{+}\right)$B cells was not different between $C D 19^{\text {Cre/WT }} ;$ Notch $2^{\triangle P E S T / \triangle P E S T}$ and control mice of either sex (Table 3). Flow cytometry of spleen cells revealed a sixfold to sevenfold increase in MZ B cells and a decrease in follicular B cells in CD19 ${ }^{\text {Cre/WT}}$; Notch $2^{\triangle P E S T / \triangle P E S T}$ male and female mice when compared with control littermates (Figure 5). The mean fluorescence intensity was enhanced twofold in $\mathrm{CD} 19^{\mathrm{Cre} / W T}$; Notch $2^{\triangle P E S T / \triangle P E S T}$ mice when compared with controls. To confirm flow cytometry results, the splenic architecture was examined. The overall follicular structure and macrophage (CD169) distribution were not altered in $C D 19^{C r e / W T}$; Notch $2^{\triangle P E S T / \triangle P E S T}$ mice. However, the size of the MZ, as defined by $\operatorname{IgM}^{+}$B cells, was enlarged, whereas $\operatorname{IgM}^{+}$B cells in the white pulp (follicular B cells) were decreased in $C D 19^{C r e / W T} ;$ Notch2 $2^{\triangle P E S T / \triangle P E S T}$ mice compared with controls (Figure 5).
Induction of the NOTCH1-NICD in CD19 B-Cell Phenocopies CD19 ${ }^{\text {Cre/WT }}$;Notch2 ${ }^{\triangle P E S T / \triangle P E S T}$ Mice

To determine whether the effect on MZ B-cell allocation was specific to Notch2, the conditional activation of Notch1 was induced in B cells. Homozygous Rosa ${ }^{\text {Notchl } 1}$ mice were mated with $C D 19^{C r e / W T}$ mice. In control experiments, flow cytometry of spleen cells from CD19 Cre/WT or Rosa $a^{\text {Notch } 1}$ mice demonstrated no differences in B-cell populations when compared with wild-type littermates (data not shown). The general appearance, weight, and relative spleen size of $C D 19^{\text {Cre/WT }} ;$ Rosa ${ }^{\text {Notch } 1 / W T}$ mice were not different from those of controls (Figure 6), and Cre-mediated recombination of loxP sites flanking the STOP cassette was documented in spleen genomic DNA (Figure 6). Basal Hes5 mRNA levels were detectable in control Rosa ${ }^{\text {Notchl }}$ mice, whereas they were not detectable in either wild-type (Figure 2) or Notch2 $2^{[\triangle P E S T] C O I N /[\triangle P E S T] C O I N}$ control mice (Figure 4). Although there is no immediate explanation for this difference, it may be related to differences in colonies or the genetic manipulation of the Rosa26 locus, resulting in a 
Notch2, B Cells, and the Skeleton

Table 3 B-Cell Populations in the Bone Marrow of 2-Month-Old Notch2 ${ }^{\text {PEST }}$ and Rosa ${ }^{\text {Notch1 }}$ Mice and Sex-Matched Littermate Controls

\begin{tabular}{|c|c|c|c|c|}
\hline \multirow[b]{2}{*}{ Gate used } & \multicolumn{3}{|l|}{${\mathrm{B} 220^{+} \mathrm{IgM}^{-}}^{-}$} & \multirow[b]{2}{*}{$\begin{array}{l}\mathrm{IgM}^{+} \\
\text {immature B }\end{array}$} \\
\hline & $\begin{array}{l}\mathrm{CD}^{-} 9^{-} \\
\mathrm{CD}_{117^{-}} \\
\text {pre-pro-B }\end{array}$ & $\begin{array}{l}\text { CD19 }^{+} \\
\text {CD117 }^{+} \\
\text {pro-B }\end{array}$ & $\begin{array}{l}\text { CD19 }^{+} \\
\text {CD117 }^{-} \\
\text {pre-B }\end{array}$ & \\
\hline \multicolumn{5}{|l|}{ Notch $^{\triangle P E S T / \triangle P E S T}$} \\
\hline \multicolumn{5}{|l|}{ Male } \\
\hline Control & $30.5 \pm 5.1$ & $0.5 \pm 0.1$ & $66.0 \pm 6.1$ & $74.6 \pm 3.2$ \\
\hline Control & $29.2 \pm 3.7$ & $0.5 \pm 0.2$ & $67.3 \pm 3.5$ & $71.5 \pm 1.6$ \\
\hline Notch2 $2^{\triangle P E S T}$ & $24.7 \pm 4.4$ & $0.4 \pm 0.0$ & $72.9 \pm 4.6$ & $69.6 \pm 5.5$ \\
\hline \multicolumn{5}{|l|}{ Rosa $a^{\text {Notch1 }}$} \\
\hline \multicolumn{5}{|l|}{ Male } \\
\hline Control & $20.5 \pm 0.9$ & $1.1 \pm 0.1$ & $76.7 \pm 1.0$ & $66.1 \pm 1.8$ \\
\hline
\end{tabular}

Data are expressed as percentages within the indicated gates and represent means \pm SD for three to four biological replicates.

${ }^{*} P<0.05$ Rosa ${ }^{\text {Notch1 }}$ versus control mice by unpaired $t$-test.

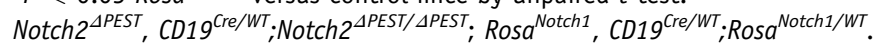

modest level of basal Notch activation in the spleen. Notch1-NICD, Hesl, and Hes5 mRNA levels were increased in splenocytes from $C D 19^{\text {Cre/WT }} ;$ Rosa $a^{\text {Notch } 1 / W T}$ mice when compared with control Rosa ${ }^{\text {Notch } / W T}$ littermates, confirming induction of Notch signaling in the spleen (Figure 6). In accordance with the modest $\mathrm{Cre}$ expression in the bone marrow, minimal evidence of Notch activation was noted in this compartment.

Flow cytometry of B cells isolated from the bone marrow demonstrated modest differences between $C D 19^{C r e / W T}$; Rosa $a^{\text {Notchl/WT }}$ and control mice in the frequency of pre-pro-B and pro-B cells in the bone marrow (Table 3). Flow cytometry of spleen cells revealed a threefold increase in MZ B cells and a decrease in follicular B cells in male and female mice when compared with littermate controls (Figure 7). The CD21/35 mean fluorescence intensity was enhanced 1.7- to 2-fold in $C D 19^{C r e / W T} ; R o s a^{\text {Notch } 1 / W T}$ mice. These findings demonstrate that activation of Notch1 in CD19-expressing cells recapitulates the splenic phenotype of the Notch2 $2^{\text {tm1.1ECan }}$ and $C D 19^{\text {Cre/WT }} ;$ Notch $2^{\triangle P E S T / \triangle P E S T}$ mice and indicates that activation of Notch signaling in $\mathrm{CD} 19^{+} \mathrm{B}$ cells, irrespective of the identity of the receptor, alters B-cell allocation in the spleen.

\section{Prolonged Activation of Notch in the B-Cell Lineage Does Not Cause a Skeletal Phenotype}

To establish whether the osteopenic phenotype previously reported in global Notch $2^{\text {tml.1ECan }}$ and Notch2 $2^{\triangle P E S T / W T}$ germline mutants is secondary to the effect of Notch2 in B cells, the skeletal phenotype of $C D 19^{\text {Cre/WT }} ;$ Notch $2^{\triangle P E S T / \triangle P E S T}$ mice and Notch2 $2^{[\triangle P E S T] C O I N /[\triangle P E S T] C O I N}$ littermate controls was determined..$^{26,35}$ In preliminary studies, CD19 Cre/WT, Notch2 $2^{[\triangle P E S T] C O I N /[\triangle P E S T] C O I N}$, and Rosa ${ }^{\text {NotchI/WT }}$ mice do not have a skeletal phenotype, as determined by $\mu \mathrm{CT}$ of distal femurs, when compared with wild-type controls ${ }^{35,40}$ (data not shown). Femoral architectural analysis by $\mu \mathrm{CT}$ of male and female 2-month-old CD19 ${ }^{\text {Cre/WT }} ;$ Notch2 $2^{\triangle P E S T / \triangle P E S T}$ mice revealed no differences when compared with wild-type sex-matched littermate controls (Table 4).

To verify that Notch activation in B cells does not alter skeletal homeostasis, the phenotype of $C D 19^{\mathrm{Cre} / W T}$; Rosa $a^{\text {Notch } 1 / W T}$ mice was examined. Analysis of the distal femur by $\mu \mathrm{CT}$ revealed that the cancellous and cortical bone of $C D 19^{C r e / W T}$; Rosa ${ }^{\text {Notchl/WT }}$ male and female mice was not different from that of Rosa $a^{\text {Notchl/WT }}$ littermate sex-matched controls (Table 5). These results demonstrate that neither the activation of Notch1 nor the activation of Notch2 in CD19-expressing cells results in a skeletal phenotype.

\section{Changes in B-Cell Allocation in the Spleen Do Not Affect the Skeleton}

To ensure that the effect of Notch2 on B-cell allocation in the spleen does not influence skeletal homeostasis, splenectomies or sham operations were performed in 1-month-old heterozygous Notch2 $2^{\text {tm1.1ECan }}$ global mutant male and female mice, known to have altered B-cell allocation in the spleen and to be osteopenic. ${ }^{26,28}$ Notch2 ${ }^{\text {tml.1ECan }}$ mice were obtained after the crossings of Notch $2^{\text {tml.1ECan }}$ heterozygous mice with wild-type mice, all in a C57BL/6J genetic background. Notch2 ${ }^{\text {tm1.1ECan }}$ mutant mice were compared with sex-matched littermate controls at 2 months of age. $\mu \mathrm{CT}$ of the distal femur confirmed that 2-month-old Notch2 $2^{\text {tm I.IECan }}$ mutant mice had a $40 \%$ to 
A

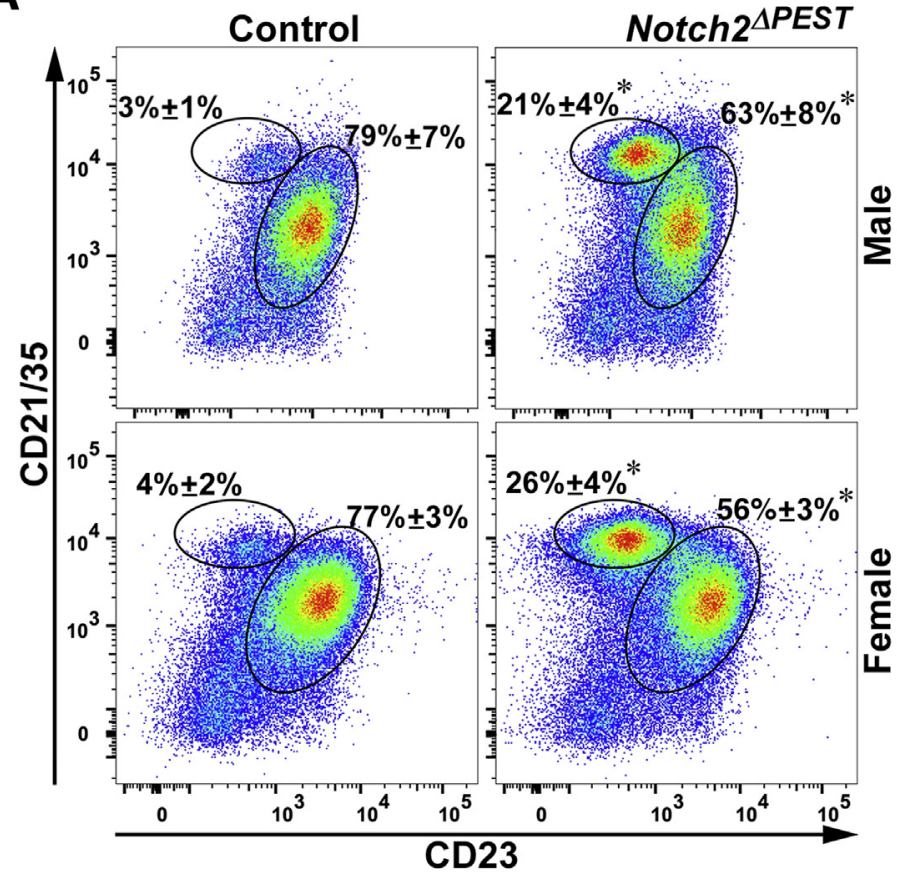

B

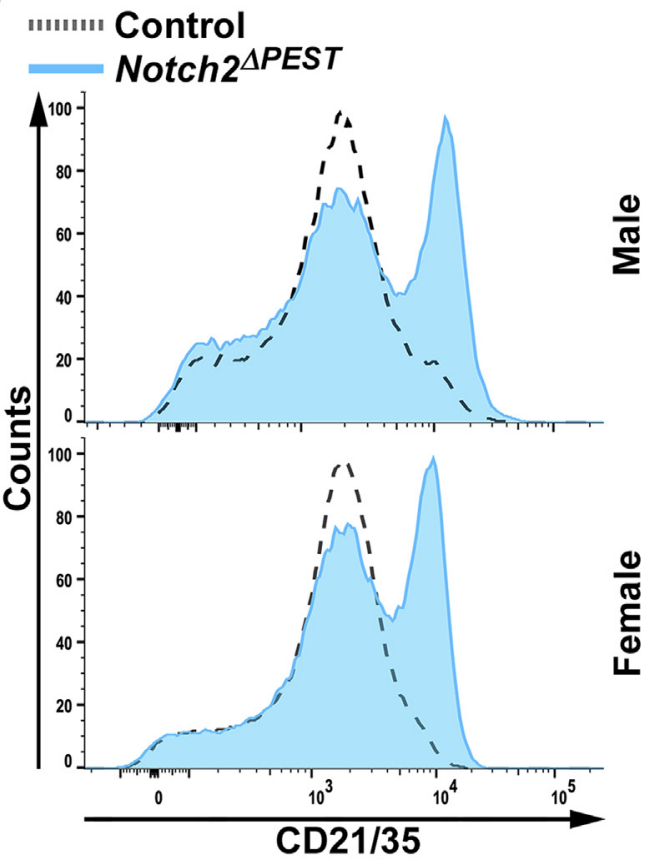

C

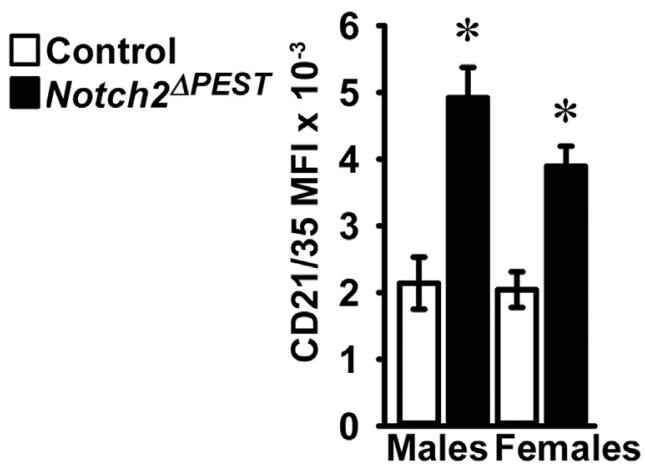

$\lg M$

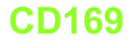

Control

$\lg M$
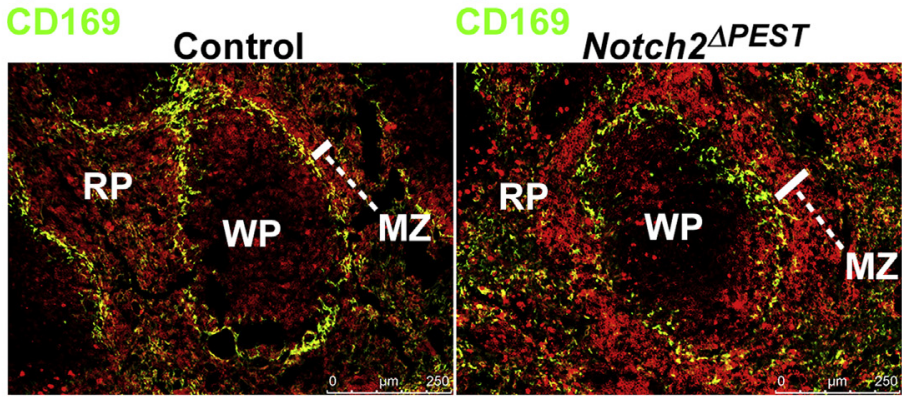

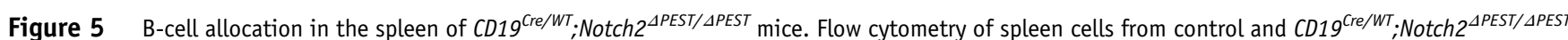

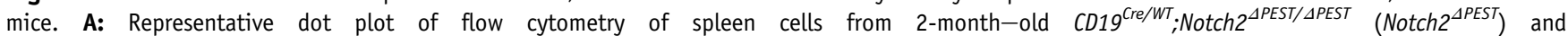
Notch2 ${ }^{[\triangle P E S T] C O I N /[\triangle P E S T] C O I N}$ control male and female sex-matched littermates. Cells were stained with anti-CD21/35 and anti-CD23 antibodies. Frequency of $\mathrm{CD} 21 / 35^{\text {high }} \mathrm{CD} 23^{-}$marginal zone (MZ) B cells and $\mathrm{CD} 21 / 35^{\text {int }} \mathrm{CD} 23^{+}$follicular B cells gated on $\mathrm{B}^{2} 20^{+} / \mathrm{IgM}^{+} \mathrm{B}$-cell populations is shown. Values represent the percentage of MZ B cells and follicular B cells. B: Histogram of the mean fluorescence intensity (MFI) of the CD21/35 cell population from 2-month-old

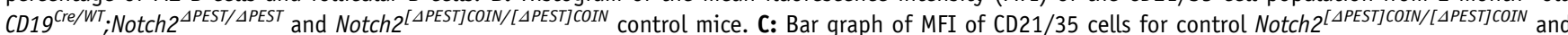
CD19 ${ }^{\text {Cre/WT }}$;Notch2 ${ }^{\triangle P E S T / \triangle P E S T}$ mice. D: Representative image of spleen follicles [white pulp (WP)] stained with anti-IgM surrounded by a CD169 ${ }^{+}$metallophilic macrophage ring, stained with anti-CD169 antibodies, separating the red pulp (RP) and defining the MZ. The presence of nucleated cells was verified by DAPI staining (not shown). Data are expressed as means \pm SD (A and $\mathbf{C}) . n=3$ to 4 biological replicates $(\mathbf{A}) ; n=4$ biological replicates $(\mathbf{C})$. ${ }^{*} P<0.05$ versus control.

$50 \%$ decrease in trabecular bone volume associated with decreased trabecular number and decreased cortical bone area. ${ }^{26,52}$ Splenectomy did not reverse the cancellous or cortical bone osteopenic phenotype of Notch2 $2^{\text {tml.1ECan }}$ mutant mice. As a result, cancellous bone volume/total volume and cortical bone area were lower in Notch $2^{\text {tm1.1ECan }}$ mice, whether they were sham operated or splenectomized (Table 6). These results confirm that the Notch2-dependent alterations in cells of the spleen are not responsible for the skeletal manifestations of Notch2 $2^{\text {tml.IECan }}$ mutant mice.

\section{Discussion}

In this study, the contribution of $\mathrm{CD} 19^{+} \mathrm{B}$ cells to the spleen and bone phenotypes of Notch2 $2^{\text {tm1.1ECan }}$ mutant mice was explored by the conditional introduction of the HCS genetic defect in the B-cell lineage. The mutations associated with the disease occur within exon 34 of $\mathrm{NOTCH} 2$, and the conditional insertion of a premature stop codon in the homologous region of the murine Notch2 locus was achieved by the generation of a COIN allele, as reported 
A

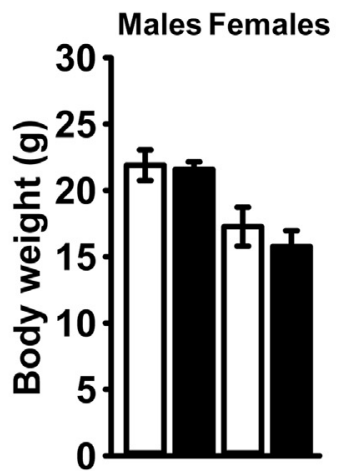

B

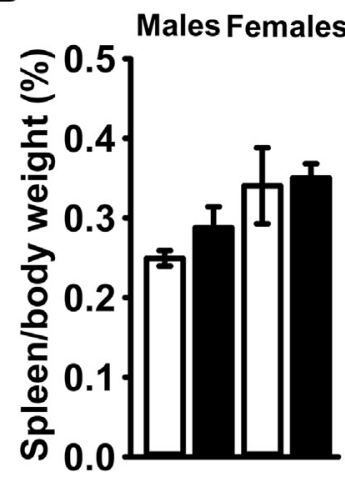

C

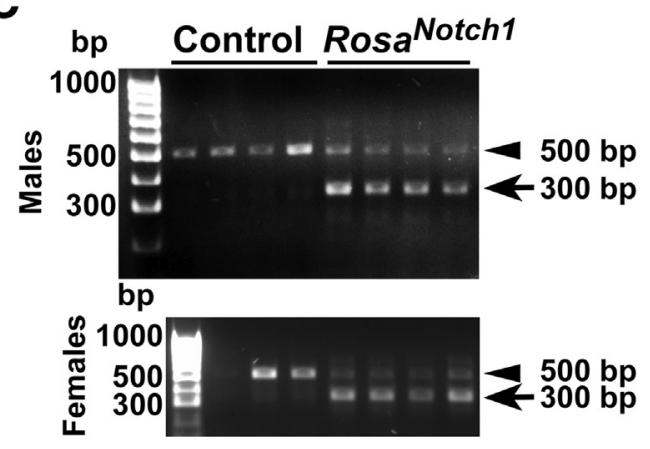

D
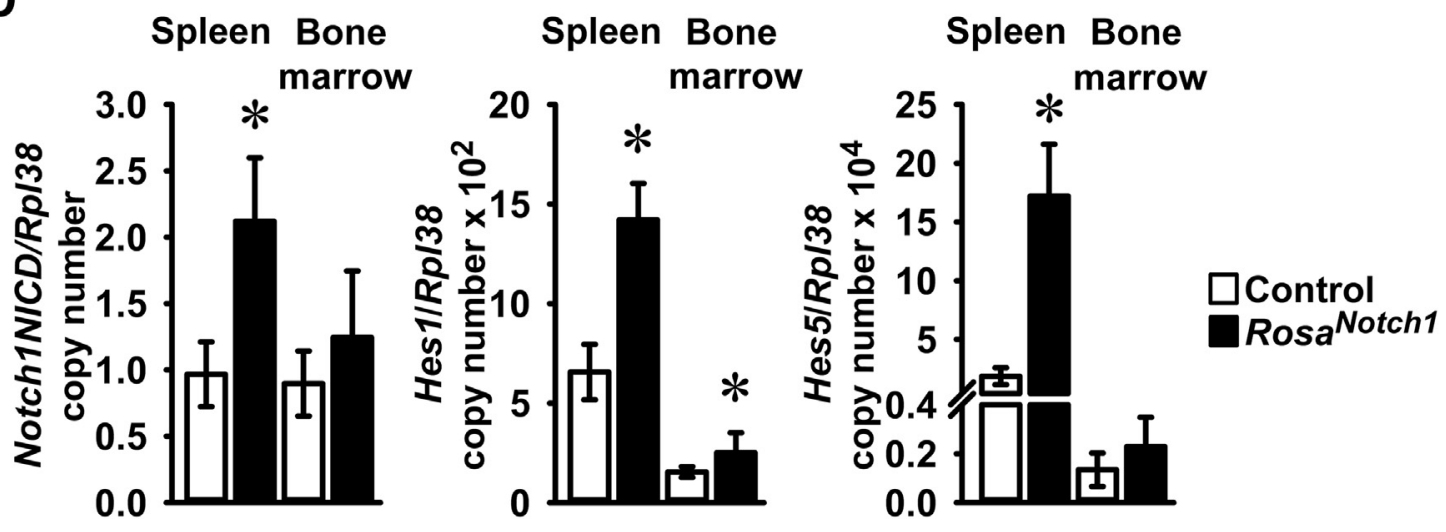

Figure 6 General appearance of $C D 19^{\text {Cre/WT }}$;Rosa $a^{\text {Notch1/WT }}$ mice and Notch signaling in the spleen and bone marrow. Weight, spleen weight, documentation

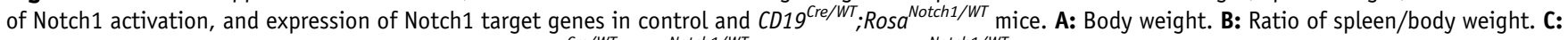
DNA was extracted from spleens of 2-month-old CD19 $9^{\text {Cre/WT }} ; R_{\text {Rosa }}^{\text {Notch1/WT }}$ and control Rosa ${ }^{\text {Notch1/WT }}$ male and female mice, and excision of the STOP was demonstrated by gel electrophoresis of PCR products obtained with primers specific for the Rosa ${ }^{\text {Notch } 1}$ allele. The arrowheads and arrows indicate the positions of the 500- and 300-bp amplicons, respectively, obtained from the intact or recombined Rosa ${ }^{\text {Notch1 }}$ alleles. D: Total RNA was extracted from spleen or bone marrow cells of 2-month-old CD1 $9^{\text {Cre/WT; }}$ Rosa ${ }^{\text {Notch1/WT }}$ and control Rosa ${ }^{\text {Notch1/WT }}$ littermates, and gene expression was measured by real-time quantitative RTPCR. Notch1NICD, Hes1, and Hes5 mRNA copy numbers corrected for Rpl38 expression are shown. Two technical replicates were used for each real-time quantitative RT-PCR. Data are expressed as means \pm SD (A, B, and D). $n=7$ control and $n=5$ CD19 ${ }^{\text {Cre } / W T}$; Rosa ${ }^{\text {Notch } 1 / W T}$ for male mice; $n=6$ control and $n=3 \mathrm{CD} 19^{\text {Cre/WT }}$; Rosa ${ }^{\text {Notch1/WT }}$ for female mice $(\mathbf{A}$ and $\mathbf{B}) ; n=8$ control and $n=5$ CD1 $9^{\text {Cre/WT }}$; Rosa $a^{\text {Notch } 1 / W T}$ biological replicates for spleen; $n=8$ control and $n=7 \mathrm{CD} 19^{\text {Cre/WT}} ;$ Rosa $^{\text {Notch1/WT }}$ biological replicates for bone marrow samples (D). ${ }^{*} P<0.05$ versus control (t-test).

previously. ${ }^{35}$ This approach allows genetic alterations to be introduced within coding exons without disrupting the expression or function of the targeted locus before the inversion of the COIN module, a goal that cannot be accomplished with a traditional Cre-loxP strategy. The Notch $2^{\triangle P E S T}$ mutants generated by germline inversion of the COIN allele expressed the Notch2 $2^{\triangle P E S T}$ transcript and phenocopied the spleen alterations present in global Notch $2^{\text {tm1.1ECan }}$ mutants. ${ }^{28}$ This confirms that the generalized expression of a Notch2 mutant lacking the PEST domain causes an MZ B-cell phenotype.

The present study demonstrates that either the induction of a Notch2 gain-of-function mutation or activation of Notch1 signaling in CD19-expressing cells alters B-cell allocation in the $\mathrm{MZ}$ of the spleen, with an increase in $\mathrm{MZ}$ $\mathrm{B}$ cells and a reduction in follicular B cells. A modest and unexplained decrease in MZ B cells was observed in Notch2 $2^{[\triangle P E S T] C O I N /[\triangle P E S T] C O I N}$ mice, before recombination, when compared with wild-type littermates. This should not influence the interpretation of the results in view of the magnitude (sixfold to sevenfold) of the increase in MZ B cells in $C D 19^{C r e / W T} ;$ Notch $2^{\triangle P E S T / \triangle P E S T}$ mice when compared with controls and the fact that they have an analogous phenotype to that of global Notch2 ${ }^{\text {tm1.1ECan }}$ mutant and of germline Notch ${ }^{\triangle P E S T}$ mice. ${ }^{28}$ There were no changes in the distribution of early $\mathrm{B}$ cells in the bone marrow after the induction of either Notch1 or Notch2, suggesting that Notch primarily affects the allocation of mature B cells in the spleen. Although lower expression of Cre recombinase in the bone marrow than in the spleen of $C D 19^{C r e / W T}$ mice, and as a consequence a lower induction of Notch target genes, was confirmed, this does not seem to be the only reason for the lack of an effect on B-cell population in the bone marrow of mice with enhanced Notch signaling. In fact, global Notch2 $2^{\text {tml.1ECan }}$ mice with a gain-of-Notch2 function exhibit an MZ spleen 
A

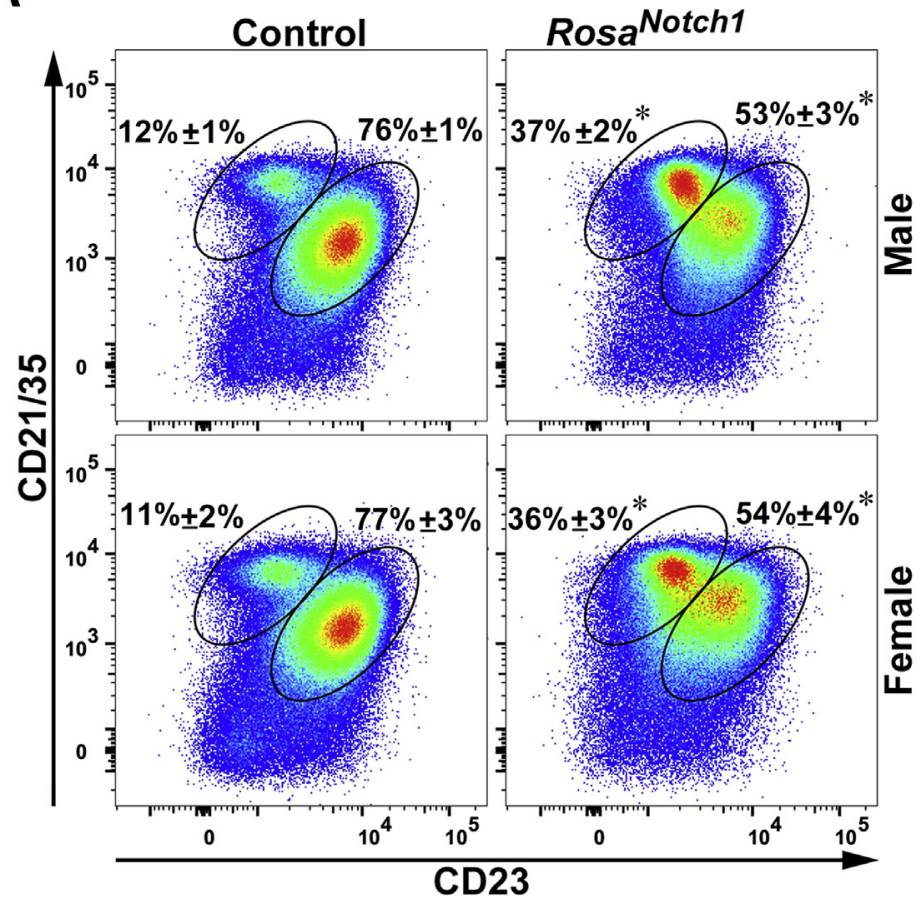

B

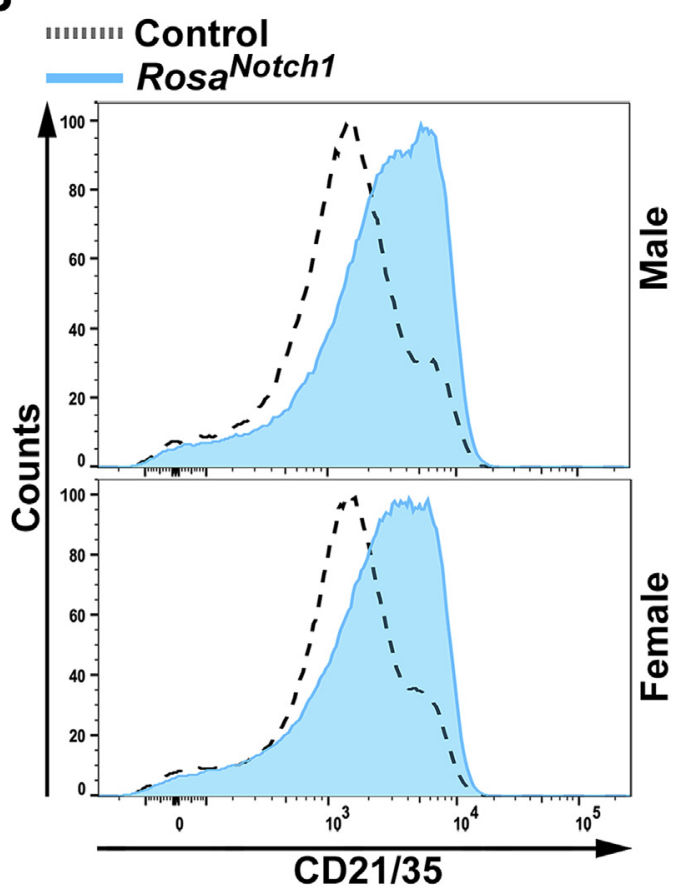

C

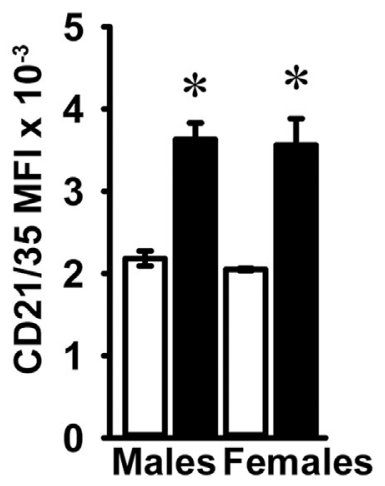

Figure 7 B-cell allocation in the spleen of $C D 19^{C r e / W T} ;$ Rosa $a^{\text {Notch1/WT }}$ mice. Flow cytometry of spleen cells from control and $C D 19^{\text {Cre/WT}} ;$ Rosa $a^{\text {Notch } 1 / W T}$ mice. A: Representative dot plot of flow cytometry of spleen cells from 2-month-old $C D 19^{\text {Cre/WT }} ;$ Rosa $^{\text {Notch1/WT }}$ and control male and female sex-matched littermates. Cells were stained with anti-CD21/35 and anti-CD23 antibodies. Frequency of CD21/ $35^{\text {high }}{ }^{2}$ D23 $3^{-}$marginal zone (MZ) B cells and $\mathrm{CD} 21 / 35^{\text {int }} \mathrm{CD} 23^{+}$follicular B cells gated on $\mathrm{B} 220^{+} / \mathrm{IgM}^{+}$ B-cell populations is shown. Values represent the percentage of MZ B cells and follicular B cells. B: Histogram of the mean fluorescence intensity (MFI) of the CD21/35 cell population from 2month-old CD19 ${ }^{\text {Cre/WT }} ;$ Rosa $a^{\text {Notch1/WT }}$ and Rosa ${ }^{\text {Notch } 1 / W T}$ control mice. C: Bar graph of MFI of the CD21/35 cells for control (white bars) and $C D 19^{\text {Cre/WT }} ;$ Rosa $^{\text {Notch1/WT }}$ (black bars) mice. Data are expressed as means $\pm \mathrm{SD}$ ( $\mathbf{A}$ and $\mathbf{C}) . n=3$ to 4 biological replicates $(\mathbf{A}$ and $\mathbf{C})$. ${ }^{\star} P<0.05$ versus control (t-test). phenotype, but no changes in the bone marrow B-cell population. The results suggest that Notch affects the allocation of mature B cells, but not the early stages of B-cell differentiation. This is in agreement with previous work demonstrating that Notch2 is preferentially expressed in mature B cells and Notch2 haploinsufficiency; the selective inactivation of Notch2, Adam10, or Rbpjк in CD19expressing cells results in a severe reduction in MZ mature B cells. ${ }^{13-15,53}$ Our studies also confirm work showing that the NOTCH2-NICD expression in CD19 cells drives $\mathrm{B}$ cells toward the MZ B-cell compartment at the expense of the follicular B cells. ${ }^{17}$

It is of interest that the spleen phenotype of $C D 19^{C r e / W T}$; Notch $2^{\triangle P E S T / \triangle P E S T}$ mice was reproduced after the forced activation of Notch1 in CD19-expressing cells. These effects are possibly explained by similarities between the Notch1 and Notch2 intracellular domains and by the fact that under selected conditions, the intracellular domains of both receptors are functionally equivalent. ${ }^{54,55}$ However, this does not mean that Notch1 and Notch2 have redundant functions, because differences related to their pattern of expression and the distinct nature of their interactions with RВРЈ $\kappa$ lead to distinct cellular responses. ${ }^{7}$

Although subjects with HCS are not known to have alterations in B-cell allocation, a recent report documents splenomegaly in an affected individual. ${ }^{18}$ It is of interest that subjects with Alagille syndrome associated with JAGl mutations do not have abnormalities in B-cell populations, whereas individuals with Alagille syndrome associated with $\mathrm{NOTCH} 2$ haploinsufficiency display a marked reduction in $\operatorname{IgM}^{+} \mathrm{IgD}^{+} \mathrm{CD} 27^{+} \mathrm{MZ} \mathrm{B}$ cells, arguing for a role of Notch2 in B-cell allocation in humans. ${ }^{16}$ Humans have a less well-developed MZ of the spleen than rodents, and the organization of the marginal and follicular zone in the human spleen differs from that in the mouse. ${ }^{56}$ 
Notch2, B Cells, and the Skeleton

Table 4 Femoral Microarchitecture Assessed by $\mu \mathrm{CT}$ of 2-Month-Old Notch2 ${ }^{\triangle P E S T}$ Mice and Sex-Matched Littermate Controls

\begin{tabular}{|c|c|c|c|c|}
\hline \multirow[b]{2}{*}{ Variable } & \multicolumn{2}{|l|}{ Males } & \multicolumn{2}{|l|}{ Females } \\
\hline & Control $(n=5)$ & Notch2 $^{\triangle P E S T}(n=7)$ & Control $(n=7)$ & Notch2 $^{\triangle P E S T}(n=6)$ \\
\hline \multicolumn{5}{|l|}{ Distal femur trabecular bone } \\
\hline Trabecular separation, $\mu \mathrm{m}$ & $153 \pm 11$ & $143 \pm 17$ & $226 \pm 9$ & $214 \pm 27$ \\
\hline Trabecular no., $1 / \mathrm{mm}$ & $6.5 \pm 0.5$ & $7.0 \pm 0.7$ & $4.5 \pm 0.2$ & $4.8 \pm 0.6$ \\
\hline Trabecular thickness, $\mu \mathrm{m}$ & $33 \pm 1$ & $35 \pm 1$ & $28 \pm 1$ & $28 \pm 3$ \\
\hline Density of material, $\mathrm{mg} \mathrm{HA} / \mathrm{cm}^{3}$ & $1053 \pm 10$ & $1047 \pm 21$ & $1039 \pm 16$ & $1027 \pm 18$ \\
\hline \multicolumn{5}{|l|}{ Femoral midshaft cortical bone } \\
\hline Bone/total volume, $\%$ & $91.4 \pm 0.8$ & $91.4 \pm 1.4$ & $86.1 \pm 1.3$ & $86.6 \pm 2.2$ \\
\hline Porosity, \% & $8.6 \pm 0.8$ & $8.3 \pm 1.4$ & $13.9 \pm 1.3$ & $13.4 \pm 2.2$ \\
\hline Cortical thickness, $\mu \mathrm{m}$ & $178 \pm 6$ & $177 \pm 13$ & $130 \pm 7$ & $130 \pm 17$ \\
\hline Density of material, $\mathrm{mg} \mathrm{HA} / \mathrm{cm}^{3}$ & $1138 \pm 37$ & $1131 \pm 33$ & $1136 \pm 22$ & $1122 \pm 2.5$ \\
\hline
\end{tabular}

$\mu \mathrm{CT}$ was performed at the femoral distal end for trabecular or midshaft for cortical bone. Data are expressed as means \pm SD of biological replicates. $\mu \mathrm{CT}$, microcomputed tomography; HA, hydroxyapatite; Notch2 ${ }^{\triangle P E S T}, \mathrm{CD} 19^{\text {Cre/WT }} ;$ Notch $2^{\triangle P E S T / \triangle P E S T}$.

The conditional HCS mutant model described in this study reaffirmed that Notch2 increases the transcript levels of Hes 1 and Hes 5 in the spleen, confirming that Notch2 activates RBPJ $\kappa$-mediated Notch signaling in this organ. The increase in mRNA levels for these Notch target genes reflects activation of the Notch canonical pathway but does not imply that HES proteins mediate the effect of Notch2 in the spleen.
Although the selective introduction of the HCS mutation in CD19 B cells caused an MZ B-cell phenotype, it did not cause cancellous or cortical bone osteopenia. This would indicate that the roles of Notch2 in B-cell allocation and skeletal homeostasis are not interdependent. The observations are consistent with recent work demonstrating that the skeletal phenotype of Notch2 $2^{\text {tml.lECan }}$ mutants is largely secondary to a direct effect of Notch2 in osteoblasts and, to

Table 5 Femoral Microarchitecture Assessed by $\mu \mathrm{CT}$ of 2-Month-0ld Rosa ${ }^{\text {Notch1 }}$ Mice and Sex-Matched Littermate Controls

\begin{tabular}{|c|c|c|c|c|}
\hline \multirow[b]{2}{*}{ Variables } & \multicolumn{2}{|l|}{ Males } & \multicolumn{2}{|l|}{ Females } \\
\hline & Control $(n=7)$ & $\operatorname{Rosa}^{\text {Notch1 }}(n=5)$ & Control $(n=6)$ & $\operatorname{Rosa}^{\text {Notch } 1}(n=3)$ \\
\hline \multicolumn{5}{|l|}{ Distal femur trabecular bone } \\
\hline Trabecular separation, $\mu \mathrm{m}$ & $188 \pm 28$ & $199 \pm 21$ & $228 \pm 17$ & $227 \pm 12$ \\
\hline Trabecular no., $1 / \mathrm{mm}$ & $5.4 \pm 0.8$ & $5.1 \pm 0.6$ & $4.4 \pm 0.3$ & $4.4 \pm 0.2$ \\
\hline Trabecular thickness, $\mu \mathrm{m}$ & $33 \pm 5$ & $32 \pm 4$ & $30 \pm 2$ & $28 \pm 1$ \\
\hline Density of material, $\mathrm{mg} \mathrm{HA} / \mathrm{cm}^{3}$ & $1023 \pm 16$ & $1017 \pm 16$ & $1009 \pm 17$ & $1014 \pm 13$ \\
\hline \multicolumn{5}{|l|}{ Femoral midshaft cortical bone } \\
\hline Bone/total volume, \% & $86.6 \pm 2.7$ & $85.7 \pm 2.6$ & $86.6 \pm 2.9$ & $85.6 \pm 1.2$ \\
\hline Porosity, \% & $13.4 \pm 2.7$ & $14.3 \pm 2.6$ & $13.4 \pm 2.9$ & $14.4 \pm 1.2$ \\
\hline Cortical thickness, $\mu \mathrm{m}$ & $148 \pm 20$ & $138 \pm 19$ & $133 \pm 17$ & $130 \pm 7$ \\
\hline Density of material, $\mathrm{mg} \mathrm{HA} / \mathrm{cm}^{3}$ & $1137 \pm 14$ & $1132 \pm 11$ & $1158 \pm 22$ & $1141 \pm 1.2$ \\
\hline
\end{tabular}

$\mu \mathrm{CT}$ was performed at the femoral distal end for trabecular or midshaft for cortical bone. Data are expressed as means \pm SD of biological replicates. $\mu \mathrm{CT}$, microcomputed tomography; HA, hydroxyapatite; Rosa ${ }^{\text {Notch1 }}, C_{1} 19^{\text {Cre/WT }} ; R_{\text {Rosa }}^{\text {Notch1/WT }}$. 
Table 6 Femoral Microarchitecture Assessed by $\mu \mathrm{CT}$ of 2-Month-Old Notch2 ${ }^{\text {tm1.1ECan }}$ Mutant Mice and Sex-Matched Control Littermates Subjected to Splenectomies or Sham Interventions

\begin{tabular}{|c|c|c|c|c|}
\hline \multirow[b]{2}{*}{ Males } & \multicolumn{2}{|l|}{ Sham } & \multicolumn{2}{|l|}{ Splenectomy } \\
\hline & Control $(n=6)$ & Notch2 ${ }^{\text {tm1.1ECan }}(n=5)$ & Control $(n=7)$ & Notch2 ${ }^{\text {tm1.1ECan }}(n=4)$ \\
\hline \multicolumn{5}{|l|}{ Distal femur trabecular bone } \\
\hline Bone/total volume, \% & $8.8 \pm 2.7$ & $5.2 \pm 3.2$ & $11.1 \pm 3.5$ & $4.0 \pm 2.9^{*}$ \\
\hline Trabecular separation, $\mu \mathrm{m}$ & $207 \pm 11$ & $281 \pm 39 *$ & $201 \pm 36$ & $333 \pm 79 *$ \\
\hline Trabecular no., $1 / \mathrm{mm}$ & $4.9 \pm 0.3$ & $3.7 \pm 0.6^{*}$ & $5.1 \pm 0.8$ & $3.2 \pm 0.8^{*}$ \\
\hline Trabecular thickness, $\mu \mathrm{m}$ & $39 \pm 6$ & $35 \pm 7$ & $44 \pm 5$ & $32 \pm 6^{*}$ \\
\hline Connectivity density, $1 / \mathrm{mm}^{3}$ & $215 \pm 71$ & $123 \pm 105$ & $269 \pm 83$ & $85 \pm 76^{*}$ \\
\hline Structure-model index & $2.8 \pm 0.3$ & $3.1 \pm 0.4$ & $2.7 \pm 0.3$ & $3.1 \pm 0.5^{*}$ \\
\hline Density of material, $\mathrm{mg} \mathrm{HA} / \mathrm{cm}^{3}$ & $855 \pm 18$ & $819 \pm 26^{*}$ & $867 \pm 25$ & $800 \pm 29^{*}$ \\
\hline \multicolumn{5}{|l|}{ Femoral midshaft cortical bone } \\
\hline Bone/total volume, \% & $87.5 \pm 1.3$ & $83.9 \pm 4.6^{*}$ & $87.8 \pm 1.6$ & $83.8 \pm 2.6^{*}$ \\
\hline Porosity, \% & $12.5 \pm 1.3$ & $16.1 \pm 4.6^{*}$ & $12.2 \pm 1.6$ & $16.2 \pm 2.6^{*}$ \\
\hline Cortical thickness, $\mu \mathrm{m}$ & $148 \pm 13$ & $119 \pm 21^{*}$ & $152 \pm 11$ & $116 \pm 13^{*}$ \\
\hline Total area, $\mathrm{mm}^{2}$ & $1.8 \pm 0.3$ & $1.6 \pm 0.3$ & $1.9 \pm 0.2$ & $1.7 \pm 0.2^{*}$ \\
\hline Bone area, $\mathrm{mm}^{2}$ & $0.8 \pm 0.1$ & $0.6 \pm 0.1^{*}$ & $0.8 \pm 0.1$ & $0.6 \pm 0.1^{*}$ \\
\hline Periosteal perimeter, $\mathrm{mm}$ & $4.8 \pm 0.3$ & $4.4 \pm 0.5$ & $4.9 \pm 0.3$ & $4.7 \pm 0.3^{*}$ \\
\hline Endocortical perimeter, $\mathrm{mm}$ & $3.6 \pm 0.2$ & $3.4 \pm 0.3$ & $3.7 \pm 0.3$ & $3.7 \pm 0.3$ \\
\hline \multirow[t]{2}{*}{ Density of material, $\mathrm{mg} \mathrm{HA} / \mathrm{cm}^{3}$} & $1119 \pm 16$ & $1093 \pm 35$ & $1123 \pm 21$ & $1083 \pm 22^{*}$ \\
\hline & \multicolumn{2}{|l|}{ Sham } & \multicolumn{2}{|l|}{ Splenectomy } \\
\hline Females & Control $(n=5)$ & Notch2 ${ }^{\text {tm1.1ECan }}(n=5)$ & Control $(n=4)$ & Notch2 ${ }^{\text {tm1.1ECan }}(n=6)$ \\
\hline \multicolumn{5}{|l|}{ Distal femur trabecular bone } \\
\hline Bone/total volume, \% & $5.5 \pm 1.0$ & $2.6 \pm 1.1^{*}$ & $4.8 \pm 1.4$ & $2.9 \pm 1.6^{*}$ \\
\hline Trabecular separation, $\mu \mathrm{m}$ & $261 \pm 20$ & $355 \pm 72$ & $272 \pm 57$ & $402 \pm 109$ \\
\hline Trabecular no., $1 / \mathrm{mm}$ & $3.9 \pm 0.3$ & $2.9 \pm 0.6^{*}$ & $3.8 \pm 0.7$ & $2.7 \pm 0.7^{*}$ \\
\hline Trabecular thickness, $\mu \mathrm{m}$ & $35 \pm 2$ & $29 \pm 3^{*}$ & $33 \pm 1$ & $30 \pm 3$ \\
\hline Connectivity density, $1 / \mathrm{mm}^{3}$ & $158 \pm 56$ & $57 \pm 37^{*}$ & $118 \pm 54$ & $69 \pm 44$ \\
\hline Structure-model index & $2.8 \pm 0.2$ & $3.1 \pm 0.2$ & $3.0 \pm 0.1$ & $3.0 \pm 0.2$ \\
\hline Density of material, $\mathrm{mg} \mathrm{HA} / \mathrm{cm}^{3}$ & $843 \pm 16$ & $825 \pm 7$ & $844 \pm 16$ & $813 \pm 24^{*}$ \\
\hline \multicolumn{5}{|l|}{ Femoral midshaft cortical bone } \\
\hline Bone/total volume, \% & $87.1 \pm 0.8$ & $84.1 \pm 3.0$ & $85.7 \pm 2.2$ & $79.9 \pm 7.0$ \\
\hline Porosity, \% & $12.9 \pm 0.8$ & $15.9 \pm 3.0$ & $14.3 \pm 2.2$ & $20.1 \pm 7.0$ \\
\hline Cortical thickness, $\mu \mathrm{m}$ & $136 \pm 10$ & $119 \pm 18$ & $128 \pm 14$ & $101 \pm 23^{*}$ \\
\hline Total area, $\mathrm{mm}^{2}$ & $1.6 \pm 0.1$ & $1.4 \pm 0.1^{*}$ & $1.5 \pm 0.1$ & $1.5 \pm 0.1$ \\
\hline Bone area, $\mathrm{mm}^{2}$ & $0.7 \pm 0.1$ & $0.6 \pm 0.1^{*}$ & $0.6 \pm 0.1$ & $0.5 \pm 0.1^{*}$ \\
\hline Periosteal perimeter, $\mathrm{mm}$ & $4.4 \pm 0.1$ & $4.1 \pm 0.2^{*}$ & $4.4 \pm 0.1$ & $4.3 \pm 0.2$ \\
\hline Endocortical perimeter, $\mathrm{mm}$ & $3.4 \pm 0.1$ & $3.1 \pm 0.3$ & $3.4 \pm 0.1$ & $3.4 \pm 0.3$ \\
\hline Density of material, $\mathrm{mg} \mathrm{HA} / \mathrm{cm}^{3}$ & $1123 \pm 9$ & $1099 \pm 47$ & $1111 \pm 20$ & $1057 \pm 43^{*}$ \\
\hline
\end{tabular}

Notch2 $2^{\text {tm1.1ECan }}$ and control sex-matched littermates were subjected to splenectomies or sham interventions at 1 month of age and sacrificed 1 month later for analysis. $\mu \mathrm{CT}$ was performed at the femoral distal end for trabecular or midshaft for cortical bone. Data are expressed as means \pm SD of biological replicates.

${ }^{*} P<0.05$ versus control mice (two-way analysis of variance with Holm-Š́dák post-hoc analysis).

$\mu \mathrm{CT}$, microcomputed tomography; HA, hydroxyapatite.

a lesser extent, in osteoclasts. ${ }^{35,52}$ These results indicate that the activation of Notch2 in B cells in vivo has no skeletal consequences and that the effect of Notch2 on bone resorption is mostly secondary to its actions on cells of the osteoblast and osteoclast lineage.

Previous work has demonstrated that the expression of Tnfsf11 (encoding for RANKL) in CD19-expressing cells is responsible for the osteopenia that occurs after ovariectomy. ${ }^{34}$ However, Tnfsfll mRNA was not detected in $\mathrm{CD} 19^{+}$spleen cells of wild-type or Notch2 $2^{\text {tml.1ECan }}$ mice, and Tnfsfl1 transcripts were not induced in spleens of Notch $2^{\triangle P E S T}$ mice, possibly explaining the absence of a skeletal phenotype in $C D 19^{\text {Cre/WT }}$;Notch $2^{\triangle P E S T / \triangle P E S T}$ mice. Our previous work demonstrated that Notch $2^{\triangle P E S T / \triangle P E S T}$ osteoblasts express increased levels of Tnfsfl1 mRNA, suggesting that osteoblast-derived RANKL is responsible for the enhanced bone resorption in Notch $2^{\text {tml.1ECan }}$ mutant mice. $^{35,52,57}$ Similarly, a subject with HCS and severe osteoporosis was reported to present with elevated levels of RANKL in the serum. ${ }^{18}$ 
In conclusion, introduction of a Notch 2 mouse mutant lacking the PEST domain in CD19-expressing cells determines the B-cell reallocation in the spleen, but this does not alter skeletal homeostasis.

\section{Acknowledgments}

We thank Emmanuelle Six for Dll1 cDNA, Jeffrey S. Nye for Notch1 cDNA, Ryoichiro Kageyama for Hes 5 cDNA, Yasuaki Shirayoshi for Notch4 cDNA, Tabitha Eller, David Bridgewater, and Quynh-Mai Pham for technical support, and Mary Yurczak for secretarial assistance.

\section{Supplemental Data}

Supplemental material for this article can be found at https://doi.org/10.1016/j.ajpath.2018.02.010.

\section{References}

1. Schroeter EH, Kisslinger JA, Kopan R: Notch-1 signalling requires ligand-induced proteolytic release of intracellular domain. Nature 1998, 393:382-386

2. Zanotti S, Canalis E: Notch and the skeleton. Mol Cell Biol 2010, 30: 886-896

3. Kovall RA: More complicated than it looks: assembly of Notch pathway transcription complexes. Oncogene 2008, 27:5099-5109

4. Nam Y, Sliz P, Song L, Aster JC, Blacklow SC: Structural basis for cooperativity in recruitment of MAML coactivators to Notch transcription complexes. Cell 2006, 124:973-983

5. Wilson JJ, Kovall RA: Crystal structure of the CSL-Notch-Mastermind ternary complex bound to DNA. Cell 2006, 124:985-996

6. Iso T, Kedes L, Hamamori Y: HES and HERP families: multiple effectors of the Notch signaling pathway. J Cell Physiol 2003, 194: 237-255

7. Yuan Z, Friedmann DR, Vanderwielen BD, Collins KJ, Kovall RA: Characterization of CSL (CBF-1, Su(H), Lag-1) mutants reveals differences in signaling mediated by Notch1 and Notch2. J Biol Chem 2012, 287:34904-34916

8. Radtke F, Wilson A, Stark G, Bauer M, van Meerwijk J, MacDonald HR, Aguet M: Deficient T cell fate specification in mice with an induced inactivation of Notch1. Immunity 1999, 10:547-558

9. Pear WS, Aster JC: T cell acute lymphoblastic leukemia/lymphoma: a human cancer commonly associated with aberrant NOTCH1 signaling. Curr Opin Hematol 2004, 11:426-433

10. Lee SY, Kumano K, Nakazaki K, Sanada M, Matsumoto A, Yamamoto G, Nannya Y, Suzuki R, Ota S, Ota Y, Izutsu K, SakataYanagimoto M, Hangaishi A, Yagita H, Fukayama M, Seto M, Kurokawa M, Ogawa S, Chiba S: Gain-of-function mutations and copy number increases of Notch2 in diffuse large B-cell lymphoma. Cancer Sci 2009, 100:920-926

11. Rossi D, Trifonov V, Fangazio M, Bruscaggin A, Rasi S, Spina V, et al: The coding genome of splenic marginal zone lymphoma: activation of NOTCH2 and other pathways regulating marginal zone development. J Exp Med 2012, 209:1537-1551

12. Witt CM, Hurez V, Swindle CS, Hamada Y, Klug CA: Activated Notch 2 potentiates CD8 lineage maturation and promotes the selective development of B1 B cells. Mol Cell Biol 2003, 23:8637-8650

13. Tanigaki K, Han H, Yamamoto N, Tashiro K, Ikegawa M, Kuroda K, Suzuki A, Nakano T, Honjo T: Notch-RBP-J signaling is involved in cell fate determination of marginal zone B cells. Nat Immunol 2002, $3: 443-450$
14. Saito T, Chiba S, Ichikawa M, Kunisato A, Asai T, Shimizu K, Yamaguchi T, Yamamoto G, Seo S, Kumano K, NakagamiYamaguchi E, Hamada Y, Aizawa S, Hirai H: Notch2 is preferentially expressed in mature $\mathrm{B}$ cells and indispensable for marginal zone B lineage development. Immunity 2003, 18:675-685

15. Witt CM, Won WJ, Hurez V, Klug CA: Notch2 haploinsufficiency results in diminished $\mathrm{B} 1 \mathrm{~B}$ cells and a severe reduction in marginal zone B cells. J Immunol 2003, 171:2783-2788

16. Descatoire M, Weller S, Irtan S, Sarnacki S, Feuillard J, Storck S, Guiochon-Mantel A, Bouligand J, Morali A, Cohen J, Jacquemin E, Iascone M, Bole-Feysot C, Cagnard N, Weill JC, Reynaud CA: Identification of a human splenic marginal zone B cell precursor with NOTCH2-dependent differentiation properties. J Exp Med 2014, 211: $987-1000$

17. Hampel F, Ehrenberg S, Hojer C, Draeseke A, Marschall-Schroter G, Kuhn R, Mack B, Gires O, Vahl CJ, Schmidt-Supprian M, Strobl LJ, Zimber-Strobl U: CD19-independent instruction of murine marginal zone B-cell development by constitutive Notch2 signaling. Blood 2011, 118:6321-6331

18. Adami G, Rossini M, Gatti D, Orsolini G, Idolazzi L, Viapiana O, Scarpa A, Canalis E: Hajdu Cheney syndrome: report of a novel NOTCH2 mutation and treatment with denosumab. Bone 2016, 92: $150-156$

19. Canalis E, Zanotti S: Hajdu-Cheney syndrome: a review. Orphanet J Rare Dis 2014, 9:200

20. Canalis E, Zanotti S: Hajdu-Cheney syndrome, a disease associated with NOTCH2 mutations. Curr Osteoporos Rep 2016, 14:126-131

21. Gray MJ, Kim CA, Bertola DR, Arantes PR, Stewart H, Simpson MA, Irving MD, Robertson SP: Serpentine fibula polycystic kidney syndrome is part of the phenotypic spectrum of Hajdu-Cheney syndrome. Eur J Hum Genet 2012, 20:122-124

22. Isidor B, Lindenbaum $\mathrm{P}$, Pichon $\mathrm{O}$, Bezieau S, Dina C, Jacquemont S, Martin-Coignard D, Thauvin-Robinet C, Le MM, Mandel JL, David A, Faivre L, Cormier-Daire V, Redon R, Le CC: Truncating mutations in the last exon of NOTCH2 cause a rare skeletal disorder with osteoporosis. Nat Genet 2011, 43:306-308

23. Majewski J, Schwartzentruber JA, Caqueret A, Patry L, Marcadier J, Fryns JP, Boycott KM, Ste-Marie LG, McKiernan FE, Marik I, Van EH, Michaud JL, Samuels ME: Mutations in NOTCH2 in families with Hajdu-Cheney syndrome. Hum Mutat 2011, 32: $1114-1117$

24. Simpson MA, Irving MD, Asilmaz E, Gray MJ, Dafou D, Elmslie FV, Mansour S, Holder SE, Brain CE, Burton BK, Kim KH, Pauli RM, Aftimos S, Stewart H, Kim CA, Holder-Espinasse M, Robertson SP, Drake WM, Trembath RC: Mutations in NOTCH2 cause Hajdu-Cheney syndrome, a disorder of severe and progressive bone loss. Nat Genet 2011, 43:303-305

25. Zhao W, Petit E, Gafni RI, Collins MT, Robey PG, Seton M, Miller KK, Mannstadt M: Mutations in NOTCH2 in patients with Hajdu-Cheney syndrome. Osteoporos Int 2013, 24:2275-2281

26. Canalis E, Schilling L, Yee SP, Lee SK, Zanotti S: Hajdu Cheney mouse mutants exhibit osteopenia, increased osteoclastogenesis and bone resorption. J Biol Chem 2016, 291:1538-1551

27. Fukushima H, Shimizu K, Watahiki A, Hoshikawa S, Kosho T, Oba D, Sakano S, Arakaki M, Yamada A, Nagashima K, Okabe K, Fukumoto S, Jimi E, Bigas A, Nakayama KI, Nakayama K, Aoki Y, Wei W, Inuzuka H: NOTCH2 Hajdu-Cheney mutations escape $\mathrm{SCF}$ (FBW7)-dependent proteolysis to promote osteoporosis. Mol Cell 2017, 68:645-658.e5

28. Yu J, Zanotti S, Walia B, Jellison E, Sanjay A, Canalis E: The Hajdu Cheney mutation is a determinant of B-cell allocation of the splenic marginal zone. Am J Pathol 2018, 188:149-159

29. Horowitz MC, Fretz JA, Lorenzo JA: How B cells influence bone biology in health and disease. Bone 2010, 47:472-479

30. Li Y, Toraldo G, Li A, Yang X, Zhang H, Qian WP, Weitzmann MN: B cells and $\mathrm{T}$ cells are critical for the preservation of bone homeostasis and attainment of peak bone mass in vivo. Blood 2007, 109:3839-3848 
31. Manilay JO, Zouali M: Tight relationships between B lymphocytes and the skeletal system. Trends Mol Med 2014, 20:405-412

32. Li Y, Terauchi M, Vikulina T, Roser-Page S, Weitzmann MN: B cell production of both OPG and RANKL is significantly increased in aged mice. Open Bone J 2014, 6:8-17

33. Meednu N, Zhang H, Owen T, Sun W, Wang V, Cistrone C, RangelMoreno J, Xing L, Anolik JH: Production of RANKL by memory B cells: a link between B cells and bone erosion in rheumatoid arthritis. Arthritis Rheumatol 2016, 68:805-816

34. Onal $\mathrm{M}$, Xiong J, Chen X, Thostenson JD, Almeida M, Manolagas SC, O'Brien CA: Receptor activator of nuclear factor kappaB ligand (RANKL) protein expression by B lymphocytes contributes to ovariectomy-induced bone loss. J Biol Chem 2012, 287:29851-29860

35. Zanotti S, Yu J, Sanjay A, Schilling L, Schoenherr C, Economides AN, Canalis E: Sustained Notch2 signaling in osteoblasts, but not in osteoclasts, is linked to osteopenia in a mouse model of Hajdu-Cheney syndrome. J Biol Chem 2017, 292:12232-12244

36. Murtaugh LC, Stanger BZ, Kwan KM, Melton DA: Notch signaling controls multiple steps of pancreatic differentiation. Proc Natl Acad Sci U S A 2003, 100:14920-14925

37. Economides AN, Frendewey D, Yang P, Dominguez MG, Dore AT, Lobov IB, Persaud T, Rojas J, McClain J, Lengyel P, Droguett G, Chernomorsky R, Stevens S, Auerbach W, DeChiara TM, Pouyemirou W, Cruz JM Jr, Feeley K, Mellis IA, Yasenchack J, Hatsell SJ, Xie L, Latres E, Huang L, Zhang Y, Pefanis E, Skokos D, Deckelbaum RA, Croll SD, Davis S, Valenzuela DM, Gale NW, Murphy AJ, Yancopoulos GD: Conditionals by inversion provide a universal method for the generation of conditional alleles. Proc Natl Acad Sci U S A 2013, 110:E3179-E3188

38. Tang SH, Silva FJ, Tsark WM, Mann JR: A Cre/loxP-deleter transgenic line in mouse strain 129S1/SvImJ. Genesis 2002, 32:199-202

39. Rickert RC, Roes J, Rajewsky K: B lymphocyte-specific, Cremediated mutagenesis in mice. Nucleic Acids Res 1997, 25: $1317-1318$

40. Canalis E, Parker K, Feng JQ, Zanotti S: Osteoblast lineage-specific effects of notch activation in the skeleton. Endocrinology 2013, 154:623-634

41. Nazarenko I, Pires R, Lowe B, Obaidy M, Rashtchian A: Effect of primary and secondary structure of oligodeoxyribonucleotides on the fluorescent properties of conjugated dyes. Nucleic Acids Res 2002, 30:2089-2195

42. Nazarenko I, Lowe B, Darfler M, Ikonomi P, Schuster D, Rashtchian A: Multiplex quantitative PCR using self-quenched primers labeled with a single fluorophore. Nucleic Acids Res 2002, 30:e37

43. Six EM, Ndiaye D, Sauer G, Laabi Y, Athman R, Cumano A, Brou C, Israel A, Logeat F: The notch ligand Delta1 recruits Dlg1 at cell-cell contacts and regulates cell migration. J Biol Chem 2004, 279:55818-55826
44. Nye JS, Kopan R, Axel R: An activated Notch suppresses neurogenesis and myogenesis but not gliogenesis in mammalian cells. Development 1994, 120:2421-2430

45. Shirayoshi Y, Yuasa Y, Suzuki T, Sugaya K, Kawase E, Ikemura T, Nakatsuji N: Proto-oncogene of int-3, a mouse Notch homologue, is expressed in endothelial cells during early embryogenesis. Genes Cells 1997, 2:213-224

46. Akazawa C, Sasai Y, Nakanishi S, Kageyama R: Molecular characterization of a rat negative regulator with a basic helix-loop-helix structure predominantly expressed in the developing nervous system. J Biol Chem 1992, 267:21879-21885

47. Gibson DG, Young L, Chuang RY, Venter JC, Hutchison CA 3rd, Smith HO: Enzymatic assembly of DNA molecules up to several hundred kilobases. Nat Methods 2009, 6:343-345

48. Kouadjo KE, Nishida Y, Cadrin-Girard JF, Yoshioka M, St-Amand J: Housekeeping and tissue-specific genes in mouse tissues. BMC Genomics 2007, 8:127

49. Bouxsein ML, Boyd SK, Christiansen BA, Guldberg RE, Jepsen KJ, Muller R: Guidelines for assessment of bone microstructure in rodents using micro-computed tomography. J Bone Miner Res 2010, 25:1468-1486

50. Glatt V, Canalis E, Stadmeyer L, Bouxsein ML: Age-related changes in trabecular architecture differ in female and male C57BL/6J mice. J Bone Miner Res 2007, 22:1197-1207

51. Schwenk F, Sauer B, Kukoc N, Hoess R, Muller W, Kocks C, Kuhn R, Rajewsky K: Generation of Cre recombinase-specific monoclonal antibodies, able to characterize the pattern of Cre expression in cre-transgenic mouse strains. J Immunol Methods 1997 207:203-212

52. Canalis E, Sanjay A, Yu J, Zanotti S: An antibody to Notch2 reverses the osteopenic phenotype of Hajdu-Cheney mutant male mice. Endocrinology 2017, 158:730-742

53. Gibb DR, El Shikh M, Kang DJ, Rowe WJ, El Sayed R, Cichy J, Yagita H, Tew JG, Dempsey PJ, Crawford HC, Conrad DH: ADAM10 is essential for Notch2-dependent marginal zone B cell development and CD23 cleavage in vivo. J Exp Med 2010, 207:623-635

54. Zanotti S, Canalis E: Notch signaling and the skeleton. Endocr Rey 2016, 37:223-253

55. Liu Z, Brunskill E, Varnum-Finney B, Zhang C, Zhang A, Jay PY, Bernstein I, Morimoto M, Kopan R: The intracellular domains of Notch1 and Notch2 are functionally equivalent during development and carcinogenesis. Development 2015, 142:2452-2463

56. Zouali M, Richard Y: Marginal zone B-cells, a gatekeeper of innate immunity. Front Immunol 2011, 2:63

57. Vollersen N, Hermans-Borgmeyer I, Cornils K, Fehse B, Rolvien T, Triviai I, Jeschke A, Oheim R, Amling M, Schinke T, Yorgan TA: High bone turnover in mice carrying a pathogenic Notch2-mutation causing Hajdu-Cheney syndrome. J Bone Miner Res 2018, 33:70-83 